\title{
Disability and Poverty in Vietnam
}

\author{
Daniel Mont and Nguyen Viet Cuong
}

\begin{abstract}
Disability is significantly correlated with poverty in Vietnam, according to data from the 2006 Vietnam Household Living Standards Survey, especially when the extra costs of living with a disability are taken into account. This disability-poverty link is also associated with lower educational attainment, an important factor in determining poverty and productive economic activity in general, both for household-based businesses and wage employment. Not taking into account these associations and the extra costs of disability will make some poor disabled people invisible in poverty statistics and impede efforts to reduce poverty. JEL codes: I12, I31, O15
\end{abstract}

Disability and poverty are linked in developing countries (Braithwaite and Mont 2009; Fujii 2008; Mete 2008; Hoogeveen 2005; Yeo and Moore 2003; Elwan 1999). However, quantitative research in this area is usually hampered by the lack of good quality data on disability and corresponding data on consumption and other socioeconomic indicators, such as years of education.

Vietnam is an exception. The 2006 Vietnam Household Living Standards Survey (VHLSS) collected high-quality data on disability that are in line with new international recommendations, along with data on consumption and other socioeconomic indicators. ${ }^{1}$ Vietnam is thus a good case study for

Daniel Mont (dmont@worldbank.org; corresponding author ) is a senior poverty specialist at the World Bank in Hanoi. Nguyen Viet Cuong (c_nguyenviet@yahoo.com) is a researcher at the National Economics University in Hanoi. This work was supported by the Governance and Poverty Policy Analysis and Advice Program trust fund established by UK Department for International Development to support the World Bank's work on poverty, governance, and statistical capacity building in Vietnam. The findings, interpretations, and conclusions are those of the authors and do not necessarily represent the views of the International Bank for Reconstruction and Development/ The World Bank and its affiliated organizations. The authors would like to thank Mitchell Loeb, Aleksandra Posarac, Martin Rama, Kinnon Scott, and three anonymous referees for comments on earlier drafts.

1. The 2006 VHLSS was conducted by the General Statistics Office of Vietnam with technical support from the Work Bank. The survey covered 9,189 households and 39,071 individuals. The 2006 sample is representative of rural and urban areas and eight geographic regions. The disability data were collected for people ages 5 and older (36,701 people).

THE WORLD BANK ECONOMIC REVIEW, VOL. 25, NO. 2, pp. 323-359

doi:10.1093/wber/lhr019 (C) The Author 2011. Published by Oxford University Press on behalf of the International Bank for Reconstruction and Development / THE WORLD BANK. All rights reserved. For permissions, please e-mail: journals.permissions@oup.com 
exploring the relation between poverty and disability. A previous study of poverty in Vietnam in 2006 estimated that the poverty rate was 16.4 percent for people with disabilities compared with 13.5 percent for other people (Braithwaite and Mont 2009).

This gap of nearly 3 percentage points probably underestimates the impact of living with a disability. The poverty line is based on a consumption level that represents a minimum standard of living for the general population, but studies show that a given consumption level does not translate into an equivalent standard of living for people with disabilities because of their extra costs of living (Tibble 2005; Zaidi and Burchardt 2005). These costs could include additional health services, assistive devices, personal assistance (whether purchased or provided by family members, with the associated opportunity costs), and additional transportation costs, among others.

According to Amartya Sen's (1985, 1993, 1999) capabilities approach, poverty is not merely a shortage of material goods but also a lack of the capability of combining the resources at one's disposal to reach a minimum standard of living. In the United Kingdom, once the extra costs of living with a disability were accounted for, the relation between disability and poverty rose dramatically (Kuklys 2005). In that country, 23 percent of households with people with disabilities had less than 60 percent of the median income; when the additional costs of disability were taken into account, that percentage rose to more than 47 percent.

One factor usually mentioned in studies of the correlation between poverty and disability is lack of access to schooling. In a study of 11 developing countries, Filmer (2008) found that disability explained a larger part of enrollment deficits than any other characteristic examined, including gender and socioeconomic status. The relation between disability and school enrollment has been found in middle income countries as well (Mete 2008; Scott and Mete 2008).

This article examines the relationships between disability and educational attainment and employment and the potential impact on people's ability to live free of poverty. The article is structured as follows. Section I presents the definition of disability used in this article. Section II analyzes the pattern of disability and the relation between disability and poverty, employment, and education in Vietnam. Section III notes some implications of the study.

\section{Measuring Disability}

Disability is a complex phenomenon that has been measured many ways. In crafting survey questions on disability, this study follows the recommendations of the Washington Group on Disability Statistics, established by the UN 
Statistical Commission (www.cdc.gov/nchs/washington_group.htm). The approach is similar to the model that underlies the International Classification of Functioning, Disability, and Health, which focuses on people's ability to take particular actions in their current environment (WHO 2011). This approach is also embodied in the social model of disability (Altman 2001; Shakespeare and Watson 1997).

Disability is not synonymous with having a medical condition or functional limitation. Rather, disabilities are the result of an environment that erects barriers that prevent people from participating fully in the economic and social life of their communities (attending school, having a job, raising a family, participating in local governance, and so on). Thus, whether a person is considered to have a disability-and how mild or severe that disability is-depends strongly on the physical, cultural, and legal environment.

In recent years, measuring disability has focused on measuring the difficulties people have performing various activities (Mont 2007a, b). The Washington Group on Disability Statistics, with the involvement of at least 50 countries, has recommended using the presence of difficulties in a core set of basic activities_-sight, hearing, walking, cognition, communication, and self-care-as an operational proxy for a person having a functional limitation that puts him or her at risk of being disabled in the social model sense (CDC 2011). The importance of looking at the ability to perform actions, rather than the presence of a medical condition, is also recommended in Gertler and Gruber (2002). Simply asking people if they have a disability tends to identify only people with the most severe disabilities (Mont 2007a).

The threshold for when having difficulty performing activities becomes a disability is not clearly defined. In fact, limitations in functioning can be quite smoothly distributed (Loeb and Mont 2010). The analysis in this article uses two different thresholds to examine the sensitivity of the results to a low threshold $(D I S L O W)$ and a higher one $(D I S H I G H)$, which excludes people with lesser difficulties. DISLOW and DISHIGH are based on answers to the Washington Group's recommended census questions on disability that were included in the 2006 VHLSS (see box 1).

Following Loeb, Eide, and Mont (2008), the low threshold is defined as having some difficulty in at least two of the functional domains noted in box 1 or having considerable difficulty in one or more domains. The high threshold is defined as having considerable difficulty in at least one of the six functional domains. Thus, the cases where DISHIGH equals 1 is a subset of the observations where DISLOW equals 1. 


\section{BOX 1: Defining Disability}

Disability questions

Introductory phrase:

The next questions ask about difficulties you may have doing certain activities because of a HEALTH PROBLEM.

1. Do you have difficulty seeing, even if wearing glasses?

a. No - no difficulty

b. Yes - some difficulty

c. Yes - a lot of difficulty

d. Cannot do at all

Remaining questions have same response categories.

2. Do you have difficulty hearing, even if using a hearing aid?

3. Do you have difficulty walking or climbing steps?

4. Do you have difficulty remembering or concentrating?

5. Do you have difficulty (with self-care such as) washing all over or dressing?

Using your usual (customary) language, do you have difficulty communicating, for example, understanding or being understood?

DISLOW $=1$ if the respondent answers "some difficulty" to at least two of the questions, or "a lot of difficulty" or "cannot do at all" to at least one question, otherwise DISLOW $=0$.

DISHIGH $=1$ if the respondent answers "a lot of difficulty" or "cannot do at all" to at least one of the questions, otherwise DISHIGH $=0$.

Source: Washington Group 2008.

One reason why some difficulty in at least two areas is one threshold used for defining low disability relates to the survey question on vision. Minor vision difficulties, as measured by the survey question, have been positively correlated with consumption in a number of countries. This is unlike severe vision difficulties and difficulties in all the other domains, which are negatively correlated with consumption (Mont and Loeb 2008). This positive correlation could reflect the fact that people in jobs requiring more education (in other words, involving literacy) are quicker to notice minor difficulties in vision. For that reason, analysis was also conducted after discarding all vision difficulties except being unable to see. While this strengthened the relationship between disability and poverty and lowered disability prevalence, it did not qualitatively affect the results. Therefore, analyses ignoring minor vision problems are not included here. (It should be noted that minor vision problems alone are not enough to categorize someone as having a disability.)

Finally, the self-reporting nature of disability is a concern. Having difficulty undertaking a particular activity is inherently a subjective determination. Scott and Mete (2008) find that the negative relationship between poverty and disability weakens when a lower threshold is used because 
richer people are more inclined to report mild difficulties, perhaps because of higher expectations for their ability to function. (There is a similar rise in reported minor health problems moving up the income distribution.) This is another reason for using two thresholds in the analysis: the self-reporting bias is probably less for having a lot of difficulty or being unable to do something than for having only some difficulty. However, research also shows that answers tend to be more consistent for questions about having difficulties undertaking particular actions than for broader questions, such as "do you have a disability" or even "do you have a particular diagnosis," since knowledge of diagnoses is associated with access to health services (Miller, et al., 2010).

\section{ANALYSIS}

Functional limitations are not rare. Almost 16 percent of the Vietnamese population reported at least a little difficulty in one of the six functional domains included in the 2006 VHLSS (table 1). As in other countries, the rate of functional limitations increases dramatically in middle age and reaches roughly two-thirds of the population over the age of 62 . For people under 40, including children, the rate is $4-5$ percent. The gender difference is not large, no doubt due at least in part to women's longer life expectancy and thus to more age-related disabilities.

The vision domain has the largest percentage of people reporting functional difficulties; self-care has the smallest, but people with restrictions in self-care tend to have the most severe disabilities.

Except for vision, poor people and those in lower expenditure quintiles are more likely to have other functional limitations than are the nonpoor and people in high expenditure quintiles. As noted, richer people may be more likely to report vision problems as they are quicker to notice them because of the nature of their work or because the type of work they do causes more eyestrain.

Difficulties across functional domains are positively correlated. The correlation coefficient for having functional difficulties in different domains ranges from 0.2 to 0.6 (table A. 1 in the appendix). Overall, there is not a large difference in correlation coefficients of disabilities between poor people and nonpoor people. ${ }^{2}$

For estimating prevalence rates, the Washington Group recommends using the presence of at least some difficulty in functioning in any of the six functional domains (Washington Group 2008). That yields an overall disability rate in Vietnam of 15.7 percent, which is similar to reported disability prevalence

2. People are defined as poor if their per capita expenditure is lower than the general poverty line, as estimated by the World Bank and the General Statistics Office of Vietnam. The poverty line is equivalent to the expenditure level that allows people to meet their nutritional needs (food consumption of 2,100 calories a day) and some essential nonfood consumption, such as clothing and housing. The poverty line in 2006 was 2.56 million dong. 
Table 1. Percentage of People Reporting Functional Limitations by Area

Remembering

and Any

Characteristic Seeing Hearing concentrating Walking Self-care Communicating difficulty

\begin{tabular}{|c|c|c|c|c|c|c|c|}
\hline Total & $\begin{array}{c}11.36 \\
(0.24)\end{array}$ & $\begin{array}{c}3.29 \\
(0.12)\end{array}$ & $\begin{array}{c}4.74 \\
(0.15)\end{array}$ & $\begin{array}{c}6.03 \\
(0.16)\end{array}$ & $\begin{array}{c}1.93 \\
(0.08)\end{array}$ & $\begin{array}{c}2.71 \\
(0.11)\end{array}$ & $\begin{array}{c}15.74 \\
(0.27)\end{array}$ \\
\hline \multicolumn{8}{|l|}{ Gender } \\
\hline Male & $\begin{array}{c}10.16 \\
(0.27)\end{array}$ & $\begin{array}{c}3.06 \\
(0.14)\end{array}$ & $\begin{array}{c}4.12 \\
(0.17)\end{array}$ & $\begin{array}{c}4.67 \\
(0.17)\end{array}$ & $\begin{array}{c}1.84 \\
(0.11)\end{array}$ & $\begin{array}{c}2.40 \\
(0.13)\end{array}$ & $\begin{array}{c}14.49 \\
(0.31)\end{array}$ \\
\hline Female & $\begin{array}{c}12.50 \\
(0.29)\end{array}$ & $\begin{array}{c}3.51 \\
(0.15)\end{array}$ & $\begin{array}{c}5.33 \\
(0.19)\end{array}$ & $\begin{array}{c}7.34 \\
(0.22)\end{array}$ & $\begin{array}{c}2.04 \\
(0.11)\end{array}$ & $\begin{array}{c}3.01 \\
(0.14)\end{array}$ & $\begin{array}{l}16.94 \\
(0.32)\end{array}$ \\
\hline \multicolumn{8}{|l|}{ Age } \\
\hline $5-18$ & $\begin{array}{c}1.86 \\
(0.14)\end{array}$ & $\begin{array}{c}0.47 \\
(0.07)\end{array}$ & $\begin{array}{c}1.11 \\
(0.11)\end{array}$ & $\begin{array}{c}0.68 \\
(0.08)\end{array}$ & $\begin{array}{c}1.19 \\
(0.11)\end{array}$ & $\begin{array}{c}1.12 \\
(0.12)\end{array}$ & $\begin{array}{c}4.29 \\
(0.21)\end{array}$ \\
\hline $19-40$ & $\begin{array}{c}2.04 \\
(0.16)\end{array}$ & $\begin{array}{c}0.69 \\
(0.08)\end{array}$ & $\begin{array}{c}1.70 \\
(0.12)\end{array}$ & $\begin{array}{c}1.27 \\
(0.11)\end{array}$ & $\begin{array}{c}0.62 \\
(0.07)\end{array}$ & $\begin{array}{c}1.32 \\
(0.12)\end{array}$ & $\begin{array}{c}5.03 \\
(0.23)\end{array}$ \\
\hline $41-62$ & $\begin{array}{c}19.75 \\
(0.59)\end{array}$ & $\begin{array}{c}3.01 \\
(0.20)\end{array}$ & $\begin{array}{c}4.96 \\
(0.30)\end{array}$ & $\begin{array}{c}6.97 \\
(0.34)\end{array}$ & $\begin{array}{c}1.35 \\
(0.13)\end{array}$ & $\begin{array}{c}1.86 \\
(0.15)\end{array}$ & $\begin{array}{c}25.31 \\
(0.63)\end{array}$ \\
\hline $\begin{array}{l}\text { Older than } \\
\quad 62\end{array}$ & 54.16 & $\begin{array}{r}23.11 \\
(0.89)\end{array}$ & $\begin{array}{r}27.45 \\
(0.98)\end{array}$ & $\begin{array}{l}38.91 \\
(1.05)\end{array}$ & 11.04 & 15.54 & 66.84 \\
\hline \multicolumn{8}{|l|}{ Urban/rural } \\
\hline Urban & $\begin{array}{r}14.35 \\
(0.63)\end{array}$ & $\begin{array}{c}3.21 \\
(0.24)\end{array}$ & $\begin{array}{c}4.65 \\
(0.32)\end{array}$ & $\begin{array}{c}6.34 \\
(0.36)\end{array}$ & $\begin{array}{c}1.87 \\
(0.16)\end{array}$ & $\begin{array}{c}2.08 \\
(0.19)\end{array}$ & $\begin{array}{l}18.28 \\
(0.66)\end{array}$ \\
\hline Rural & $\begin{array}{c}10.26 \\
(0.24)\end{array}$ & $\begin{array}{c}3.31 \\
(0.13)\end{array}$ & $\begin{array}{c}4.77 \\
(0.16)\end{array}$ & $\begin{array}{c}5.92 \\
(0.18)\end{array}$ & $\begin{array}{c}1.96 \\
(0.09)\end{array}$ & $\begin{array}{c}2.94 \\
(0.13)\end{array}$ & $\begin{array}{l}14.81 \\
(0.28)\end{array}$ \\
\hline \multicolumn{8}{|l|}{ Region } \\
\hline $\begin{array}{l}\text { Red River } \\
\text { Delta }\end{array}$ & $\begin{array}{r}10.89 \\
(0.51)\end{array}$ & $\begin{array}{c}3.68 \\
(0.27)\end{array}$ & $\begin{array}{c}4.43 \\
(0.29)\end{array}$ & $\begin{array}{c}6.57 \\
(0.37)\end{array}$ & $\begin{array}{c}2.24 \\
(0.19)\end{array}$ & $\begin{array}{c}2.76 \\
(0.22)\end{array}$ & $\begin{array}{r}15.57 \\
(0.58)\end{array}$ \\
\hline North East & $\begin{array}{c}11.54 \\
(0.58)\end{array}$ & $\begin{array}{c}3.41 \\
(0.29)\end{array}$ & $\begin{array}{c}5.11 \\
(0.40)\end{array}$ & $\begin{array}{c}6.06 \\
(0.41)\end{array}$ & $\begin{array}{c}1.67 \\
(0.20)\end{array}$ & $\begin{array}{c}2.63 \\
(0.32)\end{array}$ & $\begin{array}{l}16.47 \\
(0.68)\end{array}$ \\
\hline North West & $\begin{array}{c}7.29 \\
(0.80)\end{array}$ & $\begin{array}{c}2.37 \\
(0.45)\end{array}$ & $\begin{array}{c}2.76 \\
(0.51)\end{array}$ & $\begin{array}{c}3.33 \\
(0.57)\end{array}$ & $\begin{array}{c}1.02 \\
(0.24)\end{array}$ & $\begin{array}{c}1.82 \\
(0.40)\end{array}$ & $\begin{array}{l}11.02 \\
(0.90)\end{array}$ \\
\hline $\begin{array}{l}\text { North } \\
\text { Central } \\
\text { Coast }\end{array}$ & 9.42 & 3.27 & 4.55 & 5.35 & 2.32 & 3.54 & 13.96 \\
\hline & $(0.59)$ & $(0.33)$ & $(0.39)$ & $(0.45)$ & $(0.27)$ & $(0.34)$ & $(0.69)$ \\
\hline $\begin{array}{l}\text { South Central } \\
\text { Coast }\end{array}$ & 10.39 & 2.97 & 3.54 & 5.50 & 2.13 & 2.18 & 14.78 \\
\hline & $(0.64)$ & $(0.31)$ & $(0.37)$ & $(0.49)$ & $(0.26)$ & $(0.26)$ & $(0.74)$ \\
\hline $\begin{array}{l}\text { Central } \\
\text { Highlands }\end{array}$ & 10.07 & 3.10 & 5.12 & 5.65 & 1.81 & 3.03 & 14.24 \\
\hline & $(0.80)$ & $(0.42)$ & $(0.56)$ & $(0.58)$ & $(0.28)$ & $(0.44)$ & $(0.90)$ \\
\hline South East & $\begin{array}{l}13.71 \\
(0.87)\end{array}$ & $\begin{array}{c}3.28 \\
(0.35)\end{array}$ & $\begin{array}{c}6.46 \\
(0.54)\end{array}$ & $\begin{array}{c}7.17 \\
(0.52)\end{array}$ & $\begin{array}{c}2.07 \\
(0.22)\end{array}$ & $\begin{array}{c}3.11 \\
(0.34)\end{array}$ & $\begin{array}{l}18.27 \\
(0.92)\end{array}$ \\
\hline Mekong & 12.57 & 3.14 & 4.30 & 5.73 & 1.51 & 2.11 & 16.23 \\
\hline & $(0.52)$ & $(0.23)$ & $(0.28)$ & $(0.30)$ & $(0.15)$ & $(0.19)$ & $(0.56)$ \\
\hline Poverty status & & & & & & & \\
\hline Nonpoor & 11.98 & 3.25 & 4.56 & 6.05 & 1.84 & 2.43 & 16.11 \\
\hline
\end{tabular}


TABLE 1. Continued

\begin{tabular}{lccccccc}
\hline \multicolumn{7}{c}{$\begin{array}{c}\text { Remembering } \\
\text { and }\end{array}$} \\
Characteristic & Seeing & Hearing & concentrating & Walking & Self-care & Communicating & $\begin{array}{c}\text { Any } \\
\text { difficulty }\end{array}$ \\
\hline Poor & $(0.27)$ & $(0.13)$ & $(0.16)$ & $(0.18)$ & $(0.09)$ & $(0.11)$ & $(0.30)$ \\
& 7.90 & 3.51 & 5.76 & 5.93 & 2.48 & 4.27 & 13.67 \\
Expenditure & $(0.44)$ & $(0.29)$ & $(0.38)$ & $(0.38)$ & $(0.22)$ & $(0.36)$ & $(0.59)$ \\
quintile & & & & & & & \\
Poorest & 8.20 & 3.46 & 5.58 & 5.89 & 2.39 & 4.12 & 13.67 \\
& $(0.39)$ & $(0.26)$ & $(0.33)$ & $(0.35)$ & $(0.20)$ & $(0.31)$ & $(0.52)$ \\
Near poorest & 10.43 & 3.80 & 4.83 & 6.13 & 1.85 & 2.61 & 15.01 \\
& $(0.42)$ & $(0.26)$ & $(0.30)$ & $(0.33)$ & $(0.17)$ & $(0.21)$ & $(0.50)$ \\
Middle & 11.11 & 3.52 & 4.61 & 5.78 & 2.02 & 2.79 & 15.21 \\
& $(0.46)$ & $(0.26)$ & $(0.31)$ & $(0.33)$ & $(0.18)$ & $(0.22)$ & $(0.53)$ \\
Near richest & 12.19 & 2.85 & 4.46 & 6.04 & 1.50 & 2.12 & 16.18 \\
& $(0.52)$ & $(0.23)$ & $(0.32)$ & $(0.35)$ & $(0.15)$ & $(0.20)$ & $(0.57)$ \\
Richest & 14.69 & 2.83 & 4.25 & 6.33 & 1.97 & 1.99 & 18.51 \\
& $(0.71)$ & $(0.25)$ & $(0.35)$ & $(0.40)$ & $(0.19)$ & $(0.20)$ & $(0.73)$ \\
\hline
\end{tabular}

Note: Numbers in parentheses are robust standard errors clustered at the commune level. The sample selection of the 2006 Vietnam Households Living Standards Survey follows a method of stratified random cluster sampling. The survey samples households in all rural and urban provinces of Vietnam (rural and urban areas of all provinces are strata). There were 64 provinces in 2006 and 128 strata. In each stratum, communes were selected randomly as a primary sampling unit. In each commune, three households were selected randomly. This study uses Stata to calculate the standard errors for complex survey data (svy commands in Stata). The standard error computation takes into account the effects of survey design, such as sampling weights and correlation between households within a primary sampling unit.

Source: Authors' analysis based on the 2006 Vietnam Household Living Standards Survey.

rates in many other countries that rely on a similar approach (for example, 12.2 percent for the United Kingdom, 14.5 percent for Brazil, 18.5 percent for Canada, and 19.4 percent for the United States; Mont 2007a).

This study, however, follows Loeb, Eide, and Mont (2008) in using a more restrictive threshold for DISLOW, for two reasons: to avoid the problems associated with responses to the survey question on vision, and to reduce possible false positives (people who might have a low level of functional limitation in one domain that is unlikely to have a substantial impact on their life).

Disabilities related to mental health are particularly difficult to capture in surveys and generally require detailed instruments that are not feasible for standard household surveys. Therefore, people with psychological disabilitiesespecially mild and moderate ones-are probably not identified by the questions included in the VHLSS. People with severe mental disabilities that affect their ability to care for themselves are generally identified by the survey questions, but some people with psychological disabilities may be left out because of the episodic nature of some mental disabilities. To the extent that people 
Table 2. Percentage Disabled by Disability Threshold, Gender, and Age

\begin{tabular}{|c|c|c|c|c|c|c|}
\hline \multirow[b]{2}{*}{ Characteristic } & \multirow[b]{2}{*}{ DISLOW } & \multirow[b]{2}{*}{ DISHIGH } & \multicolumn{2}{|c|}{$\begin{array}{l}\text { Counting vision } \\
\text { difficulties only if } \\
\text { unable to see }\end{array}$} & \multirow{2}{*}{$\begin{array}{l}\text { Blind } \\
\text { people }\end{array}$} & \multirow{2}{*}{$\begin{array}{c}\text { People with } \\
\text { low vision }\end{array}$} \\
\hline & & & DISLOW & DISHIGH & & \\
\hline Total & $\begin{array}{c}7.56 \\
(0.18)\end{array}$ & $\begin{array}{c}3.60 \\
(0.12)\end{array}$ & $\begin{array}{c}5.33 \\
(0.15)\end{array}$ & $\begin{array}{l}2.97 \\
(0.11)\end{array}$ & $\begin{array}{c}0.22 \\
(0.03)\end{array}$ & $\begin{array}{l}11.14 \\
(0.24)\end{array}$ \\
\hline \multicolumn{7}{|l|}{ Gender } \\
\hline Male & $\begin{array}{c}6.57 \\
(0.21)\end{array}$ & $\begin{array}{c}3.19 \\
(0.15)\end{array}$ & $\begin{array}{c}4.72 \\
(0.18)\end{array}$ & $\begin{array}{l}2.70 \\
(0.14)\end{array}$ & $\begin{array}{c}0.21 \\
(0.04)\end{array}$ & $\begin{array}{c}9.95 \\
(0.27)\end{array}$ \\
\hline Female & $\begin{array}{c}8.50 \\
(0.24)\end{array}$ & $\begin{array}{c}4.00 \\
(0.16)\end{array}$ & $\begin{array}{c}5.91 \\
(0.20)\end{array}$ & $\begin{array}{l}3.23 \\
(0.15)\end{array}$ & $\begin{array}{c}0.23 \\
(0.04)\end{array}$ & $\begin{array}{l}12.28 \\
(0.29)\end{array}$ \\
\hline \multicolumn{7}{|l|}{ Age } \\
\hline $5-18$ & $\begin{array}{c}1.63 \\
(0.13)\end{array}$ & $\begin{array}{l}1.09 \\
(0.11)\end{array}$ & $\begin{array}{l}1.51 \\
(0.13)\end{array}$ & $\begin{array}{l}1.01 \\
(0.11)\end{array}$ & $\begin{array}{c}0.03 \\
(0.02)\end{array}$ & $\begin{array}{l}1.83 \\
(0.14)\end{array}$ \\
\hline $19-40$ & $\begin{array}{c}2.02 \\
(0.14)\end{array}$ & $\begin{array}{l}1.54 \\
(0.12)\end{array}$ & $\begin{array}{c}1.69 \\
(0.13)\end{array}$ & $\begin{array}{l}1.35 \\
(0.12)\end{array}$ & $\begin{array}{c}0.10 \\
(0.03)\end{array}$ & $\begin{array}{c}1.94 \\
(0.16)\end{array}$ \\
\hline $41-62$ & $\begin{array}{c}8.49 \\
(0.37)\end{array}$ & $\begin{array}{c}3.26 \\
(0.20)\end{array}$ & $\begin{array}{c}4.81 \\
(0.27)\end{array}$ & $\begin{array}{c}2.49 \\
(0.18)\end{array}$ & $\begin{array}{c}0.12 \\
(0.04)\end{array}$ & $\begin{array}{l}19.62 \\
(0.59)\end{array}$ \\
\hline Older than 62 & $\begin{array}{l}45.20 \\
(1.05)\end{array}$ & $\begin{array}{c}20.59 \\
(0.79)\end{array}$ & $\begin{array}{l}33.02 \\
(0.98)\end{array}$ & $\begin{array}{l}16.83 \\
(0.72)\end{array}$ & $\begin{array}{c}1.59 \\
(0.24)\end{array}$ & $\begin{array}{l}52.57 \\
(1.10)\end{array}$ \\
\hline \multicolumn{7}{|l|}{ Urban/rural } \\
\hline Urban & $\begin{array}{c}7.56 \\
(0.40)\end{array}$ & $\begin{array}{c}3.40 \\
(0.25)\end{array}$ & $\begin{array}{c}5.16 \\
(0.31)\end{array}$ & $\begin{array}{c}2.75 \\
(0.23)\end{array}$ & $\begin{array}{c}0.22 \\
(0.06)\end{array}$ & $\begin{array}{c}14.13 \\
(0.62)\end{array}$ \\
\hline Rural & $\begin{array}{c}7.55 \\
(0.20)\end{array}$ & $\begin{array}{c}3.68 \\
(0.13)\end{array}$ & $\begin{array}{c}5.39 \\
(0.17)\end{array}$ & $\begin{array}{l}3.05 \\
(0.12)\end{array}$ & $\begin{array}{c}0.22 \\
(0.03)\end{array}$ & $\begin{array}{c}10.04 \\
(0.24)\end{array}$ \\
\hline \multicolumn{7}{|l|}{ Region } \\
\hline Red River Delta & $\begin{array}{c}7.74 \\
(0.39)\end{array}$ & $\begin{array}{c}3.79 \\
(0.26)\end{array}$ & $\begin{array}{c}5.39 \\
(0.31)\end{array}$ & $\begin{array}{c}3.16 \\
(0.24)\end{array}$ & $\begin{array}{c}0.18 \\
(0.05)\end{array}$ & $\begin{array}{c}10.71 \\
(0.50)\end{array}$ \\
\hline North East & $\begin{array}{c}7.43 \\
(0.44)\end{array}$ & $\begin{array}{c}2.95 \\
(0.26)\end{array}$ & $\begin{array}{c}5.22 \\
(0.37)\end{array}$ & $\begin{array}{c}2.48 \\
(0.24)\end{array}$ & $\begin{array}{c}0.18 \\
(0.06)\end{array}$ & $\begin{array}{c}11.36 \\
(0.58)\end{array}$ \\
\hline North West & $\begin{array}{c}4.75 \\
(0.65)\end{array}$ & $\begin{array}{c}2.09 \\
(0.38)\end{array}$ & $\begin{array}{c}3.21 \\
(0.54)\end{array}$ & $\begin{array}{l}2.00 \\
(0.38)\end{array}$ & $\begin{array}{c}0.00 \\
(0.00)\end{array}$ & $\begin{array}{c}7.29 \\
(0.80)\end{array}$ \\
\hline North Central Coast & $\begin{array}{c}7.05 \\
(0.48)\end{array}$ & $\begin{array}{c}3.81 \\
(0.34)\end{array}$ & $\begin{array}{c}5.56 \\
(0.41)\end{array}$ & $\begin{array}{c}3.35 \\
(0.31)\end{array}$ & $\begin{array}{c}0.20 \\
(0.07)\end{array}$ & $\begin{array}{c}9.22 \\
(0.58)\end{array}$ \\
\hline South Central Coast & $\begin{array}{c}6.53 \\
(0.50)\end{array}$ & $\begin{array}{c}3.81 \\
(0.37)\end{array}$ & $\begin{array}{c}4.73 \\
(0.42)\end{array}$ & $\begin{array}{c}3.14 \\
(0.33)\end{array}$ & $\begin{array}{c}0.24 \\
(0.09)\end{array}$ & $\begin{array}{c}10.16 \\
(0.64)\end{array}$ \\
\hline Central Highlands & $\begin{array}{c}7.49 \\
(0.66)\end{array}$ & $\begin{array}{c}3.39 \\
(0.42)\end{array}$ & $\begin{array}{c}5.37 \\
(0.52)\end{array}$ & $\begin{array}{c}2.53 \\
(0.35)\end{array}$ & $\begin{array}{c}0.17 \\
(0.09)\end{array}$ & $\begin{array}{c}9.90 \\
(0.79)\end{array}$ \\
\hline South East & $\begin{array}{c}8.87 \\
(0.64)\end{array}$ & $\begin{array}{c}4.04 \\
(0.38)\end{array}$ & $\begin{array}{c}6.27 \\
(0.49)\end{array}$ & $\begin{array}{c}3.28 \\
(0.35)\end{array}$ & $\begin{array}{c}0.35 \\
(0.10)\end{array}$ & $\begin{array}{l}13.36 \\
(0.85)\end{array}$ \\
\hline Mekong River Delta & $\begin{array}{c}7.58 \\
(0.37)\end{array}$ & $\begin{array}{c}3.50 \\
(0.22)\end{array}$ & $\begin{array}{c}4.98 \\
(0.29)\end{array}$ & $\begin{array}{c}2.76 \\
(0.20)\end{array}$ & $\begin{array}{c}0.24 \\
(0.06)\end{array}$ & $\begin{array}{c}12.33 \\
(0.52)\end{array}$ \\
\hline Poverty status & & & & & & \\
\hline Nonpoor & $\begin{array}{c}7.39 \\
(0.20)\end{array}$ & $\begin{array}{c}3.44 \\
(0.12)\end{array}$ & $\begin{array}{c}5.11 \\
(0.16)\end{array}$ & $\begin{array}{c}2.81 \\
(0.11)\end{array}$ & $\begin{array}{c}0.20 \\
(0.03)\end{array}$ & $\begin{array}{c}11.79 \\
(0.27)\end{array}$ \\
\hline Poor & $\begin{array}{c}8.50 \\
(0.45)\end{array}$ & $\begin{array}{c}4.50 \\
(0.33)\end{array}$ & $\begin{array}{c}6.56 \\
(0.39)\end{array}$ & $\begin{array}{c}3.85 \\
(0.30)\end{array}$ & $\begin{array}{c}0.36 \\
(0.09)\end{array}$ & $\begin{array}{c}7.54 \\
(0.42)\end{array}$ \\
\hline $\begin{array}{l}\text { Expenditure quintile } \\
\text { Poorest }\end{array}$ & 8.13 & 4.19 & 6.32 & 3.59 & 0.29 & 7.90 \\
\hline
\end{tabular}


TABLE 2. Continued

\begin{tabular}{lcccccc}
\hline & \multicolumn{5}{c}{$\begin{array}{c}\text { Counting vision } \\
\text { difficulties only if } \\
\text { unable to see }\end{array}$} \\
\cline { 3 - 6 } Characteristic & DISLOW & DISHIGH & DISLOW & DISHIGH & $\begin{array}{c}\text { Blind } \\
\text { people }\end{array}$ & $\begin{array}{c}\text { People with } \\
\text { low vision }\end{array}$ \\
\hline Near poorest & $(0.40)$ & $(0.28)$ & $(0.35)$ & $(0.25)$ & $(0.07)$ & $(0.38)$ \\
Middle & 7.87 & 3.75 & 5.52 & 3.11 & 0.19 & 10.24 \\
& $(0.38)$ & $(0.26)$ & $(0.32)$ & $(0.23)$ & $(0.06)$ & $(0.42)$ \\
Near richest & 7.53 & 3.71 & 5.16 & 3.01 & 0.19 & 10.92 \\
Richest & $(0.38)$ & $(0.25)$ & $(0.31)$ & $(0.23)$ & $(0.05)$ & $(0.46)$ \\
& 7.01 & 3.10 & 4.80 & 2.50 & 0.15 & 12.04 \\
& $(0.37)$ & $(0.23)$ & $(0.31)$ & $(0.21)$ & $(0.05)$ & $(0.52)$ \\
& 7.28 & 3.30 & 4.89 & 2.68 & 0.28 & 14.41 \\
& $(0.45)$ & $(0.26)$ & $(0.35)$ & $(0.23)$ & $(0.08)$ & $(0.69)$ \\
\hline
\end{tabular}

Note: Numbers in parentheses are robust standard errors clustered at the commune level.

Source: Authors' analysis based on the 2006 Vietnam Household Living Standards Survey.

with psychological disabilities are not accounted for, the prevalence rates are underestimated, as are any negative associations with employment, education, and poverty.

Table 2 reports disability prevalence rates using DISHIGH and DISLOW for different categories. Rates are reported including and excluding minor or moderate vision difficulties. The more restrictive threshold measure, DISHIGH, yields a disability rate of 3.6 percent for the general population, which falls to 2.97 percent when the only vision difficulty included is blindness. The less restrictive threshold measure, DISLOW, yields a 7.56 percent prevalence rate, which falls to 5.33 percent when blindness is the only vision difficulty considered.

More than 29 percent of the people categorized as disabled by DISLOW are disabled because of minor vision difficulties. Many of these people appear to acquire minor vision problems in middle age. The rate of low-vision difficulties jumps tenfold between ages 19-40 and ages 41-62 and more than doubles after age 62.

Patterns by gender and age are not affected by which definition of disability is used. Girls and women have a slightly higher disability rate, and disability increases with age, reaching very high levels after age 62 . Nearly half of the elderly have a disability under the low threshold measure. Poor people and people in low expenditure quintiles have slightly higher rates of disability as measured by DISLOW and DISHIGH than nonpoor people and people in high expenditure quintiles. 
The number of households affected by disability is much larger than the prevalence rate. Using DISLOW, 23.4 percent of households include a person with a disability. Using DISHIGH, that percentage drops to 12.4. Thus, even with a more conservative measure of disability, nearly one in eight Vietnamese live in a household that includes a person with a disability, so the costs of disability are borne by a broader population than those experiencing the disability directly.

Household heads account for 44.7 percent of disabled people when the DISLOW threshold is used and 33.6 percent when DISHIGH is used (table A.2 in the appendix). The rate is higher than for the general population because household heads tend to be older and age is positively correlated with disability.

As expected, households that include a person with a disability are overrepresented in the lower consumption quintiles. When DISHIGHNV is used to exclude any problems with minor to moderate vision difficulties, more than 13 percent of households in the bottom consumption quintile include a person with a disability compared with about 10.5 percent for the general population.

The correlation between low income and people with disabilities is heightened when people with mild and moderate vision difficulties are excluded. That group is actually slightly underrepresented in the bottom quintile. As stated earlier, this may be the result of people who lack reading skills not registering age-related mild losses in vision. However, as noted earlier, the association between disability and poverty is probably understated because it fails to account for the associated costs of living with a disability.

\section{Cost of Disability}

The Zaidi and Burchardt (2005) method of accounting for disability, applied in Braithwaite and Mont (2009), was used to estimate the extra costs of disability, with an expanded set of assets used in the asset index. That method begins by constructing an asset index as a measure of the standard of living, $S$, and regresses it on per capita expenditure, $Y$, disability status, $D$, and a vector of household characteristics, $\mathrm{X}$ :

$$
S=a \ln (Y)+b D+c X+\varepsilon .
$$

Then, the extra cost of disability is approximately equal to $-b / a$. Conceptually, the idea is that, with other household characteristics held constant, a certain level of expenditure (or income) is associated with a certain 
Table 3. Poverty Rates by Disability Status and Other Characteristics, with and without the Extra Costs of Disability

\begin{tabular}{|c|c|c|c|}
\hline \multirow[b]{2}{*}{ Characteristic } & \multicolumn{2}{|c|}{ General poverty line } & \multirow{2}{*}{$\begin{array}{l}\text { Adjusted poverty lin } \\
\text { Disabled people }\end{array}$} \\
\hline & Nondisabled people & Disabled people & \\
\hline All & $\begin{array}{l}15.09 \\
(0.50)\end{array}$ & $\begin{array}{l}17.16 \\
(1.01)\end{array}$ & $\begin{array}{l}22.31 \\
(1.12)\end{array}$ \\
\hline \multicolumn{4}{|l|}{ Gender } \\
\hline Male & $\begin{array}{l}14.60 \\
(0.51)\end{array}$ & $\begin{array}{l}17.46 \\
(1.30)\end{array}$ & $\begin{array}{l}22.55 \\
(1.42)\end{array}$ \\
\hline Female & $\begin{array}{l}15.57 \\
(0.53)\end{array}$ & $\begin{array}{l}16.94 \\
(1.13)\end{array}$ & $\begin{array}{l}22.13 \\
(1.26)\end{array}$ \\
\hline \multicolumn{4}{|l|}{ Age } \\
\hline $5-18$ & $\begin{array}{l}19.29 \\
(0.70)\end{array}$ & $\begin{array}{l}31.08 \\
(3.97)\end{array}$ & $\begin{array}{l}36.24 \\
(4.11)\end{array}$ \\
\hline $19-40$ & $\begin{array}{l}15.14 \\
(0.53)\end{array}$ & $\begin{array}{l}24.72 \\
(3.07)\end{array}$ & $\begin{array}{l}31.42 \\
(3.26)\end{array}$ \\
\hline $41-62$ & $\begin{array}{c}9.93 \\
(0.46)\end{array}$ & $\begin{array}{l}11.9 \\
(1.35)\end{array}$ & $\begin{array}{l}15.28 \\
(1.51)\end{array}$ \\
\hline Older than 62 & $\begin{array}{l}14.45 \\
(0.99)\end{array}$ & $\begin{array}{l}17.01 \\
(1.23)\end{array}$ & $\begin{array}{l}22.82 \\
(1.39)\end{array}$ \\
\hline \multicolumn{4}{|l|}{ Urban/rural } \\
\hline Urban & $\begin{array}{c}3.61 \\
(0.58)\end{array}$ & $\begin{array}{c}5.53 \\
(1.45)\end{array}$ & $\begin{array}{c}6.63 \\
(1.51)\end{array}$ \\
\hline Rural & $\begin{array}{l}19.32 \\
(0.64)\end{array}$ & $\begin{array}{l}21.44 \\
(1.24)\end{array}$ & $\begin{array}{l}28.09 \\
(1.36)\end{array}$ \\
\hline Number of observations & 34,007 & 2,694 & 2,694 \\
\hline
\end{tabular}

Note: Numbers in parentheses are robust standard errors clustered at the commune-level.

Source: Authors' analysis based on the 2006 Vietnam Household Living Standards Survey.

standard of living as measured by asset holdings. ${ }^{3}$ If households that include people with disabilities at that level of expenditure have lower assets, the conclusion is that the gap in assets is caused by the presence of the disability. Braithwaite and Mont (2009) used the seven most commonly held assets in their index, but this might not have accounted for people with higher levels of

3. Equation (1) is equivalent to:

$$
\ln (Y)=(1 / a) S-(b / a) D-(c / a) X-(c / a) \varepsilon
$$

The difference in log per capita expenditure between people with disabilities and those without them is equal to:

$$
\Delta=\ln \left(Y_{D=1}\right)-\ln \left(Y_{D=0}\right)=-b / a .
$$

Thus, the extra cost is approximately equal to:

$$
\left(Y_{D=1}-Y_{D=0}\right) /\left(Y_{D=0}\right) \approx-b / a .
$$


wealth who were able to purchase other assets. Therefore, the asset list was expanded. ${ }^{4}$ The extra costs of disability were estimated to be 11.5 percent, slightly higher but of similar magnitude to the just over 9 percent in Braithwaite and Mont. ${ }^{5}$

There can be a problem of endogeneity of explanatory variables in equation (1). Thus, rather than estimate the causal effect of the explanatory variables in equation (1), the estimates are used to examine the difference in expenditures between people with and without disabilities once asset holdings and other observed variables are controlled for.

Table 3 compares poverty rates for people with and without disabilities by various characteristics, both with an unadjusted poverty line and with a poverty line adjusted for the extra costs of disability. Since many households that include a person with a disability are close to the poverty line, the poverty rates increase significantly when the poverty line is adjusted for the 11.5 percent extra costs of disability, especially in rural areas.

Another striking finding is the much higher rate of poverty for households that include a child or a prime age adult with disabilities (even without accounting for the extra costs of disability). Of course, the causality may go both ways. For example, poverty may lead to disability in children because of the lack of health care and proper nutrition. It may also lead to disability in adults, but it also probably limits their ability to generate a livelihood. The difference between the poverty rates for households without disabilities and those with elderly disabled members is not that high, which brings up another point: when examining the relation between disability and poverty, it is important to account not only for the severity of the disability but also for the age when it was acquired. A child with a disability might be denied access to education and training and might experience a lifetime of discrimination. An adult who acquires a disability might already have amassed certain skills and assets. And an elderly person who acquires a disability might be beyond working age, so although their families may incur certain costs in caring for them-including foregone labor income-their own earnings potential might not be relevant.

\section{Regression Analysis}

The three regressions reported in table 4 therefore account not only for the severity of disability (with separate regressions for DISLOW and DISHIGH) but also the age of onset of the disability - in particular, whether the disability began in childhood or adulthood. (The tables in this section present only the estimates of variables of interest such as DISLOW and DISHIGH. Full regression results are in the appendix.)

4. The assets included in this analysis are motorbike; wardrobe; bed; tables, chairs, and sofas; television; electric fan;. cooker; flush toilet; permanent house; and tapwater. The variable $Y$ is per capita expenditure, $D$ is DISLOW, and $\mathrm{X}$ is a vector of household characteristics.

5. The estimate of $-b / a$ is $0.115(0.2281 / 1.9768)$, with a standard error of 0.026 . The regression of the asset index is in table A.3 in the appendix. 
Taвle 4. Regressions of Natural Log of per Capita Consumption Expenditure (Log of Thousand dong)

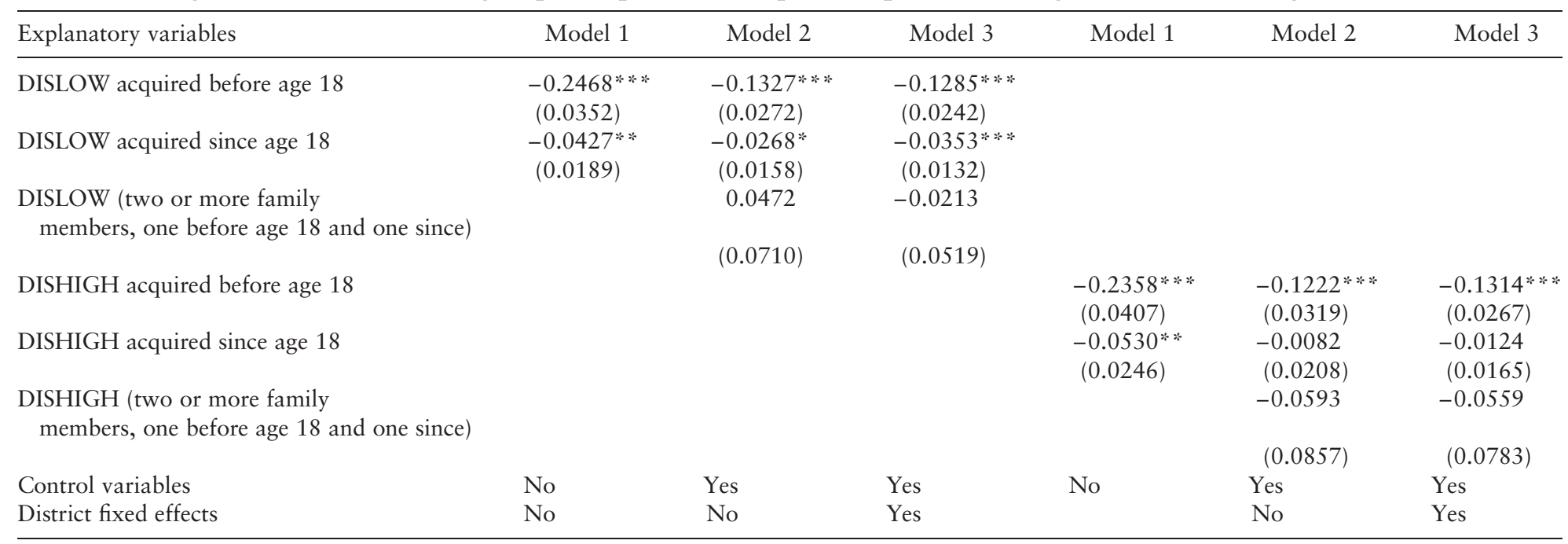

$* * *$ Significant at $p<.01 ; *$ significant at $p<.05$; significant at $p<.1$.

Note: Numbers in parentheses are robust standard errors clustered at the commune level; $n=9,189$.

Source: Authors' analysis based on the 2006 Vietnam Household Living Standards Survey. 
Model 1 includes only disability variables (no control variables). Model 2 includes several control variables. Model 3 includes district fixed-effects estimators, ${ }^{6}$ which help remove district variables that can affect both disability and household welfare, such as epidemics and calamities.

The regressions show that households that include people with disabilities are more likely to be poor, regardless of the threshold of disability or when the disability was acquired. However, the impact of the age of onset of disability is striking. The relationship is much stronger and remains statistically significant after controlling for a host of household characteristics.

Disability variables could have endogeneity problems; for example, households might have experienced shocks that made their members more likely to acquire a disability and that also lowered income and consumption. To examine this issue, regressions included disability variables with more clearly exogenous causes (war, accident, natural calamity, and birth defects) drawn from the survey question on the cause of the disability. For regressions of per capita expenditure (table A.5 in the appendix) and other the outcome variables of employment and education, these disability variables have similar effects to the overall disability variables (and thus are not reported here).

The age of onset also matters in the probability that a person with a disability is employed. With DISLOW, the negative impacts of having a disability are strongly significant but are somewhat mitigated if that disability was acquired as an adult (table 5). The same cannot be said of people considered to have a disability only when the more severe DISHIGH threshold is used: regardless of age of onset, a disability reduces the probability of a person working by about the same amount. These results hold whether looking at wage employment or household employment for people ages 16-60.

These regressions also show that completion of primary schooling is associated with a greater likelihood of working for the household business, whereas completing secondary school tends to lead more often to wage work.

After controlling for education, the results show that people with disabilities work less and that their disability is associated with less education to begin with. Enrollment rates are significantly lower for children with disabilities than for children without disabilities. For example, primary school enrollment for children ages 6-12 is nearly 96 percent for children without disabilities, but about 69 percent for children with mild, moderate, or severe disabilities. The gap is even higher when the more restrictive threshold is used. Given the importance of education to livelihoods, this puts children with disabilities, on average, at a livelihood disadvantage from the beginning. The same result is found in developed countries (Loprest and Maag 2007).

6. A $\log$ function of per capita expenditure is used because expenditure follows a log normal distribution rather than a normal distribution. Household characteristics that affect household earning include household composition, human assets, physical assets, and regional and commune characteristics (Glewwe 1991). 
Table 5. Logit Regressions of Employment by Degree of Disability for People Ages 16-60 (Odds Ratios)

\begin{tabular}{|c|c|c|c|c|c|c|}
\hline \multirow[b]{2}{*}{ Explanatory variables } & \multicolumn{6}{|c|}{ Dependent variable ( 1 if yes; 0 , otherwise) } \\
\hline & $\begin{array}{l}\text { Worked for a } \\
\text { wage or salary }\end{array}$ & $\begin{array}{c}\text { Worked for the } \\
\text { household }\end{array}$ & $\begin{array}{l}\text { Had done } \\
\text { any work }\end{array}$ & $\begin{array}{l}\text { Worked for a } \\
\text { wage or salary }\end{array}$ & $\begin{array}{l}\text { Worked for } \\
\text { the household }\end{array}$ & $\begin{array}{l}\text { Had done } \\
\text { any work }\end{array}$ \\
\hline DISLOW & $\begin{array}{l}0.3155^{* * * *} \\
(0.0648)\end{array}$ & $\begin{array}{l}0.2618 * * * \\
(0.0399)\end{array}$ & $\begin{array}{l}0.0498 * * * \\
(0.0083)\end{array}$ & & & \\
\hline $\begin{array}{l}\text { DISLOW } \\
\quad \text { from age } 18\end{array}$ & $\begin{array}{c}1.3364 \\
(0.3234)\end{array}$ & $\begin{array}{l}2.1272 * * * \\
(0.3740)\end{array}$ & $\begin{array}{l}3.0159 * * * \\
(0.5769)\end{array}$ & & & \\
\hline DISHIGH & & & & $\begin{array}{l}0.2574 * * * \\
(0.0624)\end{array}$ & $\begin{array}{l}0.2258 * * * \\
(0.0396)\end{array}$ & $\begin{array}{l}0.0390 * * * \\
(0.0073)\end{array}$ \\
\hline $\begin{array}{l}\text { DISHIGH } \\
\text { from age } 18\end{array}$ & & & & $\begin{array}{c}0.9081 \\
(0.3020)\end{array}$ & $\begin{array}{c}1.3102 \\
(0.2909)\end{array}$ & $\begin{array}{l}1.4810^{*} \\
(0.3427)\end{array}$ \\
\hline Control variables & Yes & Yes & Yes & Yes & Yes & Yes \\
\hline District fixed effects & Yes & Yes & Yes & Yes & Yes & Yes \\
\hline
\end{tabular}

$* * *$ Significant at $p<.01 ; * *$ significant at $p<.05$; significant at $p<.1$.

Note: Numbers in parentheses are robust standard errors clustered at the commune level; $n=24,710$. For the odds ratios in the logit regressions, 'significant' means 'statistically different' from one.

Source: Authors' analysis based on the 2006 Vietnam Household Living Standards Survey. 
Table 6. Logit Regressions of Education (Odds Ratios)

\begin{tabular}{|c|c|c|c|c|c|c|}
\hline Explanatory variable & Model 1 & Model 2 & Model 3 & Model 1 & Model 2 & Model 3 \\
\hline \multicolumn{7}{|c|}{ Dependent variable is school enrollment, ages 6-17 } \\
\hline DISLOW & $\begin{array}{l}0.1571 * * * \\
(0.0292)\end{array}$ & $\begin{array}{l}0.0842 * * * \\
(0.0206)\end{array}$ & $\begin{array}{l}0.0775 * * * \\
(0.0189)\end{array}$ & & & \\
\hline DISHIGH & & & & $\begin{array}{l}0.1179 * * * \\
(0.0270)\end{array}$ & $\begin{array}{l}0.0682 * * * \\
(0.0200)\end{array}$ & $\begin{array}{l}0.0586^{* * * *} \\
(0.0173)\end{array}$ \\
\hline Control variables & No & Yes & Yes & No & Yes & Yes \\
\hline District fixed effects & No & No & Yes & No & No & Yes \\
\hline \multicolumn{7}{|c|}{ Dependent variable is primary school completion, ages $18-62$} \\
\hline DISLOW by aged 10 & $\begin{array}{l}0.0631 * * * \\
(0.0117)\end{array}$ & $\begin{array}{l}0.0269 * * * \\
(0.0075)\end{array}$ & $\begin{array}{l}0.0138 * * * \\
(0.0033)\end{array}$ & & & \\
\hline DISHIGH by aged 10 & & & & $\begin{array}{l}0.0560 * * * \\
(0.0116)\end{array}$ & $\begin{array}{l}0.0223 * * * \\
(0.0070)\end{array}$ & $\begin{array}{l}0.0103 * * * \\
(0.0028)\end{array}$ \\
\hline Control variables & No & Yes & Yes & No & Yes & Yes \\
\hline District fixed effects & No & No & Yes & No & No & Yes \\
\hline \multicolumn{7}{|c|}{ Dependent variable is secondary school completion, ages $18-62$} \\
\hline DISLOW by age 17 & $\begin{array}{l}0.1520 * * * \\
(0.0426)\end{array}$ & $\begin{array}{l}0.1185 * * * \\
(0.0389)\end{array}$ & $\begin{array}{l}0.1161 * * * \\
(0.0332)\end{array}$ & & & \\
\hline DISHIGH by age 17 & & & & $\begin{array}{l}0.1812 * * * \\
(0.0536)\end{array}$ & $\begin{array}{l}0.1488 * * * \\
(0.0500)\end{array}$ & $\begin{array}{l}0.1372 * * * \\
(0.0424)\end{array}$ \\
\hline Control variables & No & Yes & Yes & No & Yes & Yes \\
\hline District fixed effects & No & No & Yes & No & No & Yes \\
\hline
\end{tabular}

$* *$ Significant at $p<.01 ; *$ significant at $p<.05$; significant at $p<.1$.

Note: Numbers in parentheses are robust standard errors clustered at the commune level. Enrolled in school $=1 ; 0$, otherwise.

Source: Authors' estimation based on the 2006 Vietnam Household Living Standards Survey. 
A series of logit regressions were estimated to explore the relation between disability and education in Vietnam. Table 6 presents the estimates for the disability variable coefficients; the full regressions are in tables A.8-A.10 in the appendix. For both DISLOW and DISHIGH, the correlation between disability and enrollment among school-age children is statistically significant at the 1 percent significance level and increases as more explanatory variables are added to the model. The odds ratios for the effect of disability on enrollment using the most inclusive specification (model 2) is 0.084 , which for DISLOW translates into children with disabilities being nearly 0.41 times less likely to attend school, once other factors are controlled for. For DISHIGH, this rises to nearly 0.47 times.

In all specifications, having a disability in childhood significantly reduces the chances of completing school for older cohorts, regardless of the definition of disability or the type of school. The odds ratios using the most inclusive specification (model 2) from the school completion logits are 0.027 (primary) and 0.119 (secondary) for DISLOW and 0.022 and 0.149 for DISHIGH. All are significant at 1 percent level.

These results show only that disability is associated with a lack of education; they do not explain the reasons behind the relationship. It could be that parents want to send their children with disabilities to school but cannot, because of barriers such as transportation difficulties, lack of accessible schools, and lack of training or acceptance by teachers. Or it could be that parents do not want to send the children to school because the returns to education for children with disabilities do not warrant the investment, whether for reasons of inherent inability to benefit from schooling or of barriers to employment (transportation, accessibility, attitudes, and so on) that prevent people with disabilities from getting a return to the human capital they acquired in school. In addition, poor parents might have limited resources for sending children to school and so may choose to spend them on their children with the highest expected returns, perceiving their children without disabilities as being the better investment.

Whatever the case, the correlation between disability and education and employment reveals that people with functional limitations have poorer outcomes than their peers without functional limitations.

\section{CONCLUSION}

Disability, whether measured by a low or a high threshold, is significantly correlated with poverty and lack of employment in Vietnam, using data from the 2006 VHLSS. After accounting for the extra costs of disability, the correlation is stronger, especially in rural areas and for households with children and prime-age adults with disabilities. That correlation is also stronger for people with more severe disabilities but is lower for people who acquire their 
disabilities when they are adults. Disability during childhood is significantly correlated with lack of educational attainment, an important determinant of poverty.

Because of the endogeneity of this system-disability causing poverty, poverty causing disability, lack of returns in the labor market affecting schooling decisions, barriers to education affecting employment opportunities-it is difficult to attribute causality. It is clear, however, that people with disabilities face more difficult and limited conditions and that the limited conditions are highly significant when the extra costs of living with a disability are taken into account. For households with people with disabilities, ignoring the extra costs of disability means that poverty statistics can miss these households whose standard of living, if the higher costs were taken into account, would be equal to that of poor households without people with disabilities .

Better data on disability need to be collected in conjunction with data on consumption and other measures of well-being. A clearer understanding of the relationship between disability and poverty and the barriers that disabled people face in fully participating in economic life will help policymakers determine where the link between disability and poverty is strongest and where the most promising and appropriate avenues are for designing interventions to weaken that link.

\section{REFERENCES}

Altman, B.M. 2001. "Disability Definitions, Models, Classification Schemes, and Applications." In Handbook of Disability Studies, ed. G.L. Albrecht, K.D. Seelman, and M. Bury, 97-122. Thousand Oaks, CA: Sage Publications.

Braithwaite, J., and D. Mont. 2009. "Disability and Poverty: A Survey of World Bank Poverty Assessments and Implications." Alter: European Journal of Disability Research 3: 219-32

CDC (Centers for Disease Control and Prevention). (2011). "Washington Group on Disability Statistics,” www.cdc.gov/nchs/washington_group.htm.

Elwan, A. 1999. "Poverty and Disability: A Survey of the Literature." SP Discussion Paper 9932, World Bank, Washington, DC.

Fujii, T. 2008. "Two-Sample Estimation of Poverty Rates for Disabled People: An Application to Tanzania." Economics and Statistics Working Paper 02-2008, Singapore Management University, Singapore.

Filmer, D. 2008. "Disability, Poverty, and Schooling in Developing Countries: Results from 11 Household Surveys." The World Bank Economic Review 22 (1):141-63.

Gertler, P., and J. Gruber. 2002. "Insuring Consumption against Illness." The American Economic Review 92 (1): 51-70.

Glewwe, P. 1991. "Investigating the Determinants of Household Welfare in Côte d'Ivoire." Journal of Development Economics 35: 307-37.

Hoogeveen, J. 2005. "Measuring Welfare for Small but Vulnerable Groups: Poverty and Disability in Uganda." Journal of African Economies 14 (4): 603-31.

Kuklys, W. 2005. Amartya Sen's Capability Approach: Theoretical Insights and Empirical Applications. Studies in Choice and Welfare. New York: Springer-Verlag.

Loeb, M.E., A.H. Eide, and D. Mont. 2008. "Approaching the Measurement of Disability Prevalence: The Case of Zambia.” Alter: European Journal of Disability Research 2 (1): 32-43. 
Loeb, M.E., and D. Mont. 2010. "A Functional Approach to Assessing Health Impacts on People with Disabilities.” Alter: European Journal of Disability Research 4 (3): 159-73.

Loprest, P., and E. Maag, 2007. "The Relationship between Early Disability Onset and Education and Employment." Journal of Vocational Rehabilitation 26 (1): 49-62.

C. Mete, ed. 2008. Economic Implications of Chronic Illness and Disease in Eastern Europe and the Former Soviet Union. Washington, DC: The World Bank.

Miller, K., D. Mont, J. Madans, B. Altman, and A. Maitland 2010. "Results of a Cross-National Structured Cognitive Interviewing Protocol to Test Measures of Disability." Quantity and Quality. 45 (4): 801-815.

Mont, D. 2007a. "Measuring Disability Prevalence." SP Discussion Paper 0706. World Bank, Washington, DC.

- 2007b. "Measuring Health and Disability." The Lancet 369: 1658-63.

Mont, D., and M. Loeb. 2008. "Beyond DALYs: Developing Indicators to Assess the Impact of Public Health Interventions on the Lives of People with Disabilities." SP Discussion Paper 0815. World Bank, Washington, DC.

Scott, K., and C. Mete. 2008. "Measurement of Disability and Linkages with Welfare, Employment, and Schooling: The Case of Uzbekistan." In Economic Implications of Chronic Illness and Disease in Eastern Europe and the Former Soviet Union, ed. C. Mete. Washington, DC: World Bank.

Sen, A. 1985. Commodities and Capabilities. Amsterdam: North Holland.

. 1993. "Capability and Well-being." In The Quality of Life, ed. M. Nussbaum, and A.K. Sen. Oxford: Clarendon Press.

-1999. Development as Freedom. Oxford: Oxford University Press.

Shakespeare, T., and N. Watson. 1997. "Defending the Social Model." Disability and Society 12 (2): 293-300.

Tibble, M. 2005. "Review of the Existing Research on the Extra Costs of Disability." Working Paper 21. Department for Work and Pensions, Leeds, UK.

Washington Group. 2008, “The Measurement of Disability: Recommendations for the 2010 Round of Censuses."Position paper available on www.cdc.gov/nchs/washington_group.htm.

WHO (World Health Organization). 2011. "International Classification of Functioning, Disability and Health (ICF).” World Health Organization, http://www.who.int/classifications/icf/en/.

Yeo, R., and K. Moore. 2003. "Including Disabled People in Poverty Reduction Work: Nothing about Us, without Us." World Development 31 (3): 571-90

Zaidi, A., and T. Burchardt. 2005. "Comparing Incomes When Needs Differ: Equivalization for the Extra Costs of Disability in the U.K." Review of Income and Wealth 51 (1): 89-114. 


\section{APPENDIX}

Table A1. Correlation Coefficients of Functional Limitations for the Poor and Nonpoor

\begin{tabular}{|c|c|c|c|c|c|c|}
\hline $\begin{array}{l}\text { Functional } \\
\text { limitation }\end{array}$ & Seeing & Hearing & $\begin{array}{c}\text { Remembering } \\
\text { and } \\
\text { concentrating }\end{array}$ & Walking & Self-care & Communicating \\
\hline \multicolumn{7}{|l|}{ Poor } \\
\hline Seeing & 1 & & & & & \\
\hline Hearing & $0.432 * * *$ & 1 & & & & \\
\hline $\begin{array}{l}\text { Remembering } \\
\text { and } \\
\text { concentrating }\end{array}$ & $0.381 * * *$ & $0.413 * * *$ & 1 & & & \\
\hline Walking & $0.523 * *$ & $0.410 * * *$ & $0.459 * * *$ & 1 & & \\
\hline Self-care & $0.204 * * *$ & $0.250 * * *$ & $0.363 * * *$ & $0.422 * * *$ & 1 & \\
\hline $\begin{array}{l}\text { Communicating } \\
\text { Nonpoor }\end{array}$ & $0.265 * * *$ & $0.332 * * *$ & $0.665 * * *$ & $0.415 * * *$ & $0.463 * * *$ & 1 \\
\hline Seeing & 1 & & & & & \\
\hline Hearing & $0.348 * * *$ & 1 & & & & \\
\hline $\begin{array}{l}\text { Remembering } \\
\text { and } \\
\text { concentrating }\end{array}$ & $0.363 * * *$ & $0.448 * * *$ & 1 & & & \\
\hline Walking & $0.401 * * *$ & $0.393 * *$ & $0.487 * * *$ & 1 & & \\
\hline Self-care & $0.198 * * *$ & $0.287 * * *$ & $0.377 * * *$ & $0.400 * * *$ & 1 & \\
\hline Communicating & $0.227 * * *$ & $0.405 * *$ & $0.605 * * *$ & $0.387 * * *$ & $0.513 * * *$ & 1 \\
\hline
\end{tabular}

$* * *$ Significant at $p<.01 ; * *$ significant at $p<.05$; significant at $p<.1$.

Source: Authors' analysis based on the 2006 Vietnam Household Living Standards Survey.

Table A2. Relation between People with DISLOW and DISHIGH and Household Head

\begin{tabular}{lccccc}
\hline Age of disabled & Head & Head's spouse & Head's children & Head's parent & Others \\
\hline DISLOW & & & & & \\
Before age 18 & 0.00 & 0.00 & 85.63 & 0.00 & 14.37 \\
& $(0.00)$ & $(0.00)$ & $(2.83)$ & $(0.00)$ & $(2.83)$ \\
$18-30$ & 4.00 & 1.56 & 90.33 & 0.00 & 4.12 \\
& $(1.68)$ & $(0.91)$ & $(2.56)$ & $(0.00)$ & $(1.80)$ \\
$31-40$ & 30.61 & 13.56 & 41.82 & 0.00 & 14.01 \\
& $(4.38)$ & $(3.27)$ & $(5.06)$ & $(0.00)$ & $(3.93)$ \\
41-50 & 53.05 & 30.34 & 8.84 & 0.76 & 7.01 \\
& $(3.10)$ & $(2.91)$ & $(2.17)$ & $(0.54)$ & $(1.73)$ \\
Older than age 50 & 51.09 & 22.08 & 0.47 & 23.53 & 2.83 \\
& $(1.04)$ & $(0.88)$ & $(0.17)$ & $(1.11)$ & $(0.42)$ \\
Total & 44.69 & 20.05 & 13.19 & 17.57 & 4.50 \\
& $(0.89)$ & $(0.75)$ & $(0.71)$ & $(0.84)$ & $(0.46)$ \\
DISHIGH & & & & & \\
Before age 18 & 0.00 & 0.00 & 84.9 & 0.00 & 15.1 \\
& $(0.00)$ & $(0.00)$ & $(3.63)$ & $(0.00)$ & $(3.63)$ \\
18-30 & 3.31 & 0.49 & 91.96 & 0.00 & 4.25 \\
\hline
\end{tabular}


TABle A2. Continued

\begin{tabular}{lccccc}
\hline Age of disabled & Head & Head's spouse & Head's children & Head's parent & Others \\
\hline \multirow{3}{*}{$31-40$} & $(1.71)$ & $(0.49)$ & $(2.68)$ & $(0.00)$ & $(2.07)$ \\
& 23.49 & 10.39 & 50.69 & 0.00 & 15.43 \\
$41-50$ & $(4.91)$ & $(3.67)$ & $(6.38)$ & $(0.00)$ & $(5.07)$ \\
& 49.91 & 17.13 & 16.45 & 0.89 & 15.63 \\
Older than age 50 & $(5.16)$ & $(3.71)$ & $(4.59)$ & $(0.88)$ & $(3.79)$ \\
\multirow{2}{*}{ Total } & 44.9 & 18.73 & 0.95 & 31.3 & 4.12 \\
& $(1.66)$ & $(1.35)$ & $(0.38)$ & $(1.70)$ & $(0.69)$ \\
& 36.33 & 14.8 & 20.9 & 21.22 & 6.75 \\
& $(1.33)$ & $(1.02)$ & $(1.23)$ & $(1.23)$ & $(0.77)$ \\
\hline
\end{tabular}

$* * *$ Significant at $p<.01 ; * *$ significant at $p<.05$; significant at $p<.1$.

Note: Number in parentheses are robust standard errors clustered at the commune level. $D I S L O W$ is the lower of two thresholds for determining when having difficulty performing activities becomes a disability; DISHIGH, the higher threshold, excludes people with lesser difficulties. DISLOW and DISHIGH (see box 1).

Source: Authors' analysis based on the 2006 Vietnam Household Living Standards Survey.

TABLE A3. Regression of Asset Index

\begin{tabular}{lccr}
\hline Explanatory variable & Coefficient & Standard error & $p>\mathrm{t}$ \\
\hline Log of per capita expenditure & 1.9768 & 0.0512 & 0.0000 \\
DISLOW & -0.2281 & 0.0508 & 0.0000 \\
Ratio of children (before age 15) & -0.3940 & 0.1096 & 0.0000 \\
Ratio of elderly (after age 60) & -0.3389 & 0.0898 & 0.0000 \\
Household size & 0.2366 & 0.0163 & 0.0000 \\
constant & -9.8166 & 0.4585 & 0.0000 \\
R-squared & 0.345 & & \\
Number of observations & 9,189 & & \\
\hline
\end{tabular}

Note: DISLOW is the lower of two thresholds for determining when having difficulty performing activities becomes a disability (see box 1 ).

Source: Authors' analysis based on the 2006 Vietnam Household Living Standards Survey. 
Table A4. Regressions of Natural Logarithm of Per Capita Consumption Expenditure (Log of Thousands of Dong)

\begin{tabular}{|c|c|c|c|c|c|c|}
\hline Explanatory variable & $\begin{array}{l}\text { Model 1: ordinary } \\
\text { least squares }\end{array}$ & $\begin{array}{l}\text { Model 2: ordinary } \\
\text { least squares }\end{array}$ & $\begin{array}{l}\text { Model 3: district } \\
\text { fixed effects }\end{array}$ & $\begin{array}{l}\text { Model 1: ordinary } \\
\text { least squares }\end{array}$ & $\begin{array}{l}\text { Model 2: ordinary } \\
\text { least squares }\end{array}$ & $\begin{array}{l}\text { Model 3: district } \\
\text { fixed effects }\end{array}$ \\
\hline \multicolumn{7}{|l|}{ DISLOW } \\
\hline Before age 18 & $\begin{array}{l}-0.2468 * * * \\
(0.0352)\end{array}$ & $\begin{array}{l}-0.1327 * * * \\
(0.0272)\end{array}$ & $\begin{array}{l}-0.1285^{* * *} \\
(0.0242)\end{array}$ & & & \\
\hline 18 and older & $\begin{array}{l}-0.0427 * * \\
(0.0189)\end{array}$ & $\begin{array}{r}-0.0268 * \\
(0.0158)\end{array}$ & $\begin{array}{l}-0.0353^{* * *} \\
(0.0132)\end{array}$ & & & \\
\hline $\begin{array}{l}\text { Two or more family members, } \\
\text { one before age } 18 \text { and one } \\
18 \text { or older }\end{array}$ & & $\begin{array}{c}0.0472 \\
(0.0710)\end{array}$ & $\begin{array}{c}-0.0213 \\
(0.0519)\end{array}$ & & & \\
\hline \multicolumn{7}{|l|}{ DISHIGH } \\
\hline Before age 18 & & & & $\begin{array}{l}-0.2358^{* * *} \\
(0.0407)\end{array}$ & $\begin{array}{l}-0.1222 * * * \\
(0.0319)\end{array}$ & $\begin{array}{l}-0.1314 * * * \\
(0.0267)\end{array}$ \\
\hline 18 and older & & & & $\begin{array}{l}-0.0530 * * \\
(0.0246)\end{array}$ & $\begin{array}{c}-0.0082 \\
(0.0208)\end{array}$ & $\begin{array}{c}-0.0124 \\
(0.0165)\end{array}$ \\
\hline $\begin{array}{l}\text { Two or more family members, } \\
\text { one before age } 18 \text { and } 18 \text { or } \\
\text { older }\end{array}$ & & & & & $\begin{array}{c}-0.0593 \\
(0.0857)\end{array}$ & $\begin{array}{c}-0.0559 \\
(0.0783)\end{array}$ \\
\hline Urban $($ yes $=1)$ & & $\begin{array}{l}0.3941 * * \\
(0.0158)\end{array}$ & $\begin{array}{l}0.1946 * * * \\
(0.0150)\end{array}$ & & $\begin{array}{l}0.3943 * * * \\
(0.0158)\end{array}$ & $\begin{array}{l}0.1955^{* * *} \\
(0.0150)\end{array}$ \\
\hline Household in Red River Delta & Omitted & & & & & \\
\hline Household in North East & & $\begin{array}{l}-0.1444 * * * \\
(0.0193)\end{array}$ & & & $\begin{array}{l}-0.1464 * * * \\
(0.0193)\end{array}$ & \\
\hline Household in North West & & $\begin{array}{l}-0.2886 * * * \\
(0.0329)\end{array}$ & & & $\begin{array}{l}-0.2894 * * * \\
(0.0329)\end{array}$ & \\
\hline \multicolumn{7}{|l|}{ Coast } \\
\hline & & $(0.0204)$ & & & $(0.0204)$ & \\
\hline $\begin{array}{l}\text { Household in South Central } \\
\text { Coast }\end{array}$ & & 0.0151 & & & 0.016 & \\
\hline
\end{tabular}


Household in Central Highlands

Household in South East

Household in Mekong River Delta

Head age

Head age squared * 1,000

Head without education degree

Head with primary school degree

Head with lower secondary school

Head with upper secondary school

Head with technical degree

Head with post-secondary school

Ratio of children (before age 15)
(0.0209)

$-0.03$

$(0.0324)$

$0.3243 * * *$

$(0.0224)$

$0.1677 * *$

$(0.0188)$

$0.0105 * * 0.0067 * * *$

$(0.0032) \quad(0.0025)$

$-0.0707 * *-0.0439$

$(0.0304) \quad(0.0237)$

Omitted

$\begin{array}{lc}0.1740 * * * & 0.1637 * * * \\ & \\ (0.0161) & (0.0131) \\ 0.2953 * * * & 0.2897 * * * \\ & (0.0143) \\ (0.0174) & 0.4235 * * * \\ 0.4799 * * * & (0.0202) \\ & 0.5206 * * * \\ (0.0249) & (0.0182) \\ 0.5657 * * * & 0.7713 * * * \\ (0.0218) & \\ 0.8632 * * * & (0.0247) \\ & -0.5352 * * * \\ (0.0295) & \end{array}$

(0.0208)

$-0.0323$

$(0.0325)$

$0.3230 * *$

$(0.0224)$

$0.1678 * * *$

$(0.0188)$

$0.0107 * * 0.0071 * * *$

$(0.0032) \quad(0.0025)$

$-0.0741 * \quad-0.0489 *$

$(0.0306) \quad(0.0237)$

$\begin{array}{ll}0.1738 * * * & 0.1638 * * * \\ (0.0161) & (0.0131) \\ 0.2961 * * * & 0.2910 * * * \\ & (0.0143) \\ (0.0174) & 0.4246 * * * \\ 0.4810 * * & (0.0203) \\ (0.0249) & 0.5223 * * * \\ 0.5667 * * & (0.0182) \\ (0.0218) & 0.7739 * * * \\ 0.8652 * * * & (0.0247) \\ & -0.5311 * * *\end{array}$


TABle A4. Continued

\begin{tabular}{|c|c|c|c|c|c|c|}
\hline Explanatory variable & $\begin{array}{l}\text { Model 1: ordinary } \\
\text { least squares }\end{array}$ & $\begin{array}{l}\text { Model 2: ordinary } \\
\text { least squares }\end{array}$ & $\begin{array}{l}\text { Model 3: district } \\
\text { fixed effects }\end{array}$ & $\begin{array}{l}\text { Model 1: ordinary } \\
\text { least squares }\end{array}$ & $\begin{array}{l}\text { Model 2: ordinary } \\
\text { least squares }\end{array}$ & $\begin{array}{l}\text { Model 3: district } \\
\text { fixed effects }\end{array}$ \\
\hline & & $(0.0329)$ & $(0.0282)$ & & $(0.0331)$ & $(0.0282)$ \\
\hline \multirow[t]{2}{*}{ Ratio of elderly (after age 60) } & & $-0.2150 * * *$ & $-0.2082 * * *$ & & $-0.2241 * * *$ & $-0.2202 * * *$ \\
\hline & & $(0.0331)$ & $(0.0267)$ & & $(0.0325)$ & $(0.0265)$ \\
\hline \multirow[t]{2}{*}{ Household size } & & $-0.0610 * * *$ & $-0.0578 * * *$ & & $-0.0616 * * *$ & $-0.0589 * *$ \\
\hline & & $(0.0040)$ & $(0.0032)$ & & $(0.0040)$ & $(0.0032)$ \\
\hline Constant & $8.5406 * * *$ & $8.1967 * * *$ & $8.3724 * * *$ & $8.5339 * * *$ & $8.1894 * * *$ & $8.3625 * * *$ \\
\hline R-squared & 0.01 & 0.48 & 0.30 & 0.01 & 0.48 & 0.30 \\
\hline Number of observations & 9,189 & & & & & \\
\hline
\end{tabular}

$* *$ Significant at $p<.01 ; *$ significant at $p<.05 ;$ significant at $p<.1$.

Note: Numbers in parentheses are robust standard errors clustered at the commune level. DISLOW is the lower of two thresholds for determining when having difficulty performing activities becomes a disability; DISHIGH, the higher threshold, excludes people with lesser difficulties. DISLOW and DISHIGH (see box 1).

Source: Authors' analysis based on the 2006 Vietnam Household Living Standards Survey. 
Table A 5. Regressions of Natural Logarithm of Per Capita Consumption Expenditure (Log of Thousand Dong): Disabilities with more Exogenous Causes

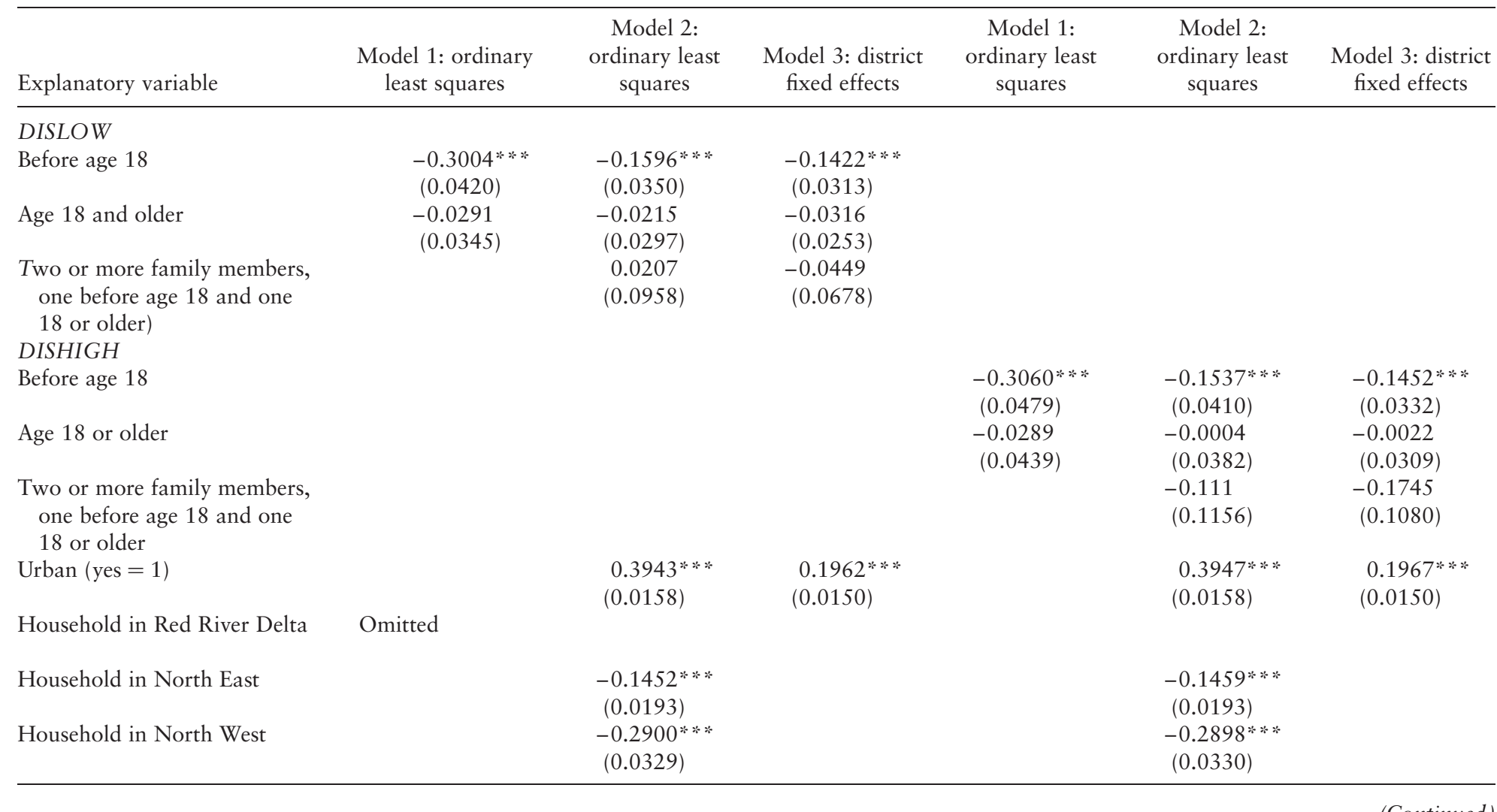


TABLE A5. Continued

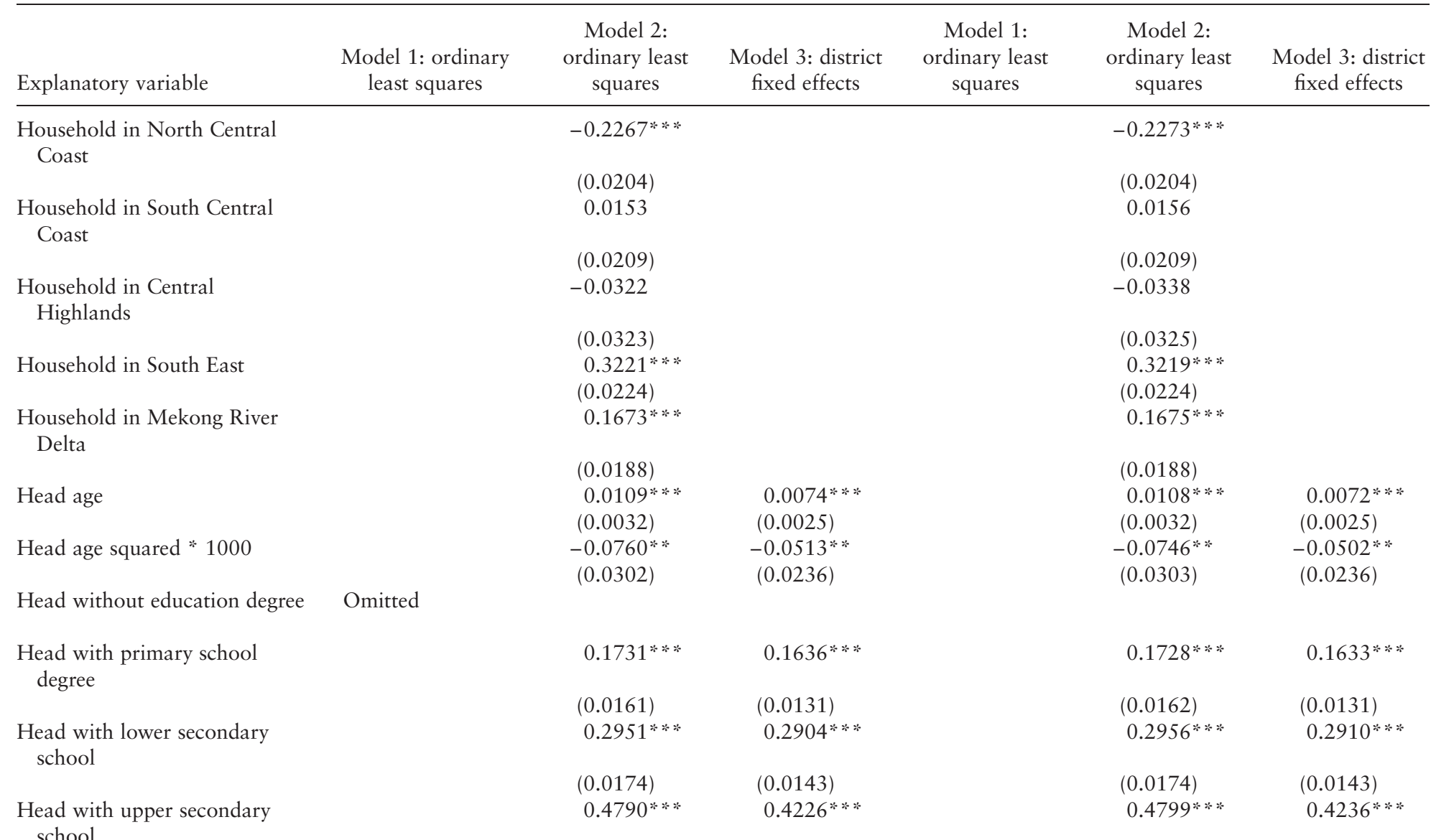




\begin{tabular}{|c|c|c|c|c|c|c|}
\hline & & $(0.0249)$ & $(0.0203)$ & & $(0.0249)$ & $(0.0203)$ \\
\hline \multirow[t]{2}{*}{ Head with technical degree } & & $0.5654 * *$ & $0.5210 * * *$ & & $0.5656 * *$ & $0.5216 * *$ \\
\hline & & $(0.0218)$ & $(0.0182)$ & & $(0.0218)$ & $(0.0182)$ \\
\hline \multirow{2}{*}{$\begin{array}{l}\text { Head with postsecondary } \\
\text { school }\end{array}$} & & $0.8642 * * *$ & $0.7728 * * *$ & & $0.8644 * * *$ & $0.7737 * *$ \\
\hline & & $(0.0295)$ & $(0.0247)$ & & $(0.0295)$ & $(0.0247)$ \\
\hline \multirow{2}{*}{$\begin{array}{l}\text { Ratio of children (before } \\
\text { age } 15 \text { ) }\end{array}$} & & $-0.5114 * * *$ & $-0.5313 * * *$ & & $-0.5120 * * *$ & $-0.5305 * *$ \\
\hline & & $(0.0329)$ & $(0.0281)$ & & $(0.0329)$ & $(0.0282)$ \\
\hline Household size & & $\begin{array}{l}-0.0620 * * * \\
(0.0040)\end{array}$ & $\begin{array}{l}-0.0591 * * * \\
(0.0032)\end{array}$ & & $\begin{array}{l}-0.0620 * * * \\
(0.0040)\end{array}$ & $\begin{array}{l}-0.0594 * * * \\
(0.0032)\end{array}$ \\
\hline Constant & $\begin{array}{l}8.5302 * * * \\
(0.0072)\end{array}$ & $\begin{array}{l}8.1885 * * \\
(0.0843)\end{array}$ & $\begin{array}{l}8.3583 * * * \\
(0.0665)\end{array}$ & $\begin{array}{l}8.5279 * * * \\
(0.0072)\end{array}$ & $\begin{array}{l}8.1908 * * * \\
(0.0843)\end{array}$ & $\begin{array}{l}8.3603 * * * \\
(0.0665)\end{array}$ \\
\hline R-squared & 0.01 & 0.48 & 0.30 & 0.01 & 0.48 & 0.30 \\
\hline Number of observation & 9,189 & & & & & \\
\hline
\end{tabular}

$* *$ Significant at $p<.01 ; *$ significant at $p<.05$; significant at $p<.1$.

Note: Numbers in parentheses are robust standard errors clustered at the commune level. DISLOW is the lower of two thresholds for determining when having difficulty performing activities becomes a disability; DISHIGH, the higher threshold, excludes people with lesser difficulties. DISLOW and DISHIGH (see box 1).

Source: Authors' analysis based on the 2006 Vietnam Household Living Standards Survey. 
Table A6. Logit Regressions of Employment by Degree of Disability on People ages 16-60 (Odds Ratios)

\begin{tabular}{|c|c|c|c|c|c|c|}
\hline Explanatory variable & $\begin{array}{l}\text { Worked for a wage or } \\
\text { salary }\end{array}$ & $\begin{array}{c}\text { Worked for the } \\
\text { household }\end{array}$ & $\begin{array}{l}\text { Had done any } \\
\text { work }\end{array}$ & $\begin{array}{l}\text { Worked for a wage or } \\
\text { salary }\end{array}$ & $\begin{array}{l}\text { Worked for the } \\
\text { household }\end{array}$ & $\begin{array}{l}\text { Had done any } \\
\text { work }\end{array}$ \\
\hline DISLOW & $\begin{array}{l}0.3506^{* * *} \\
(0.0815)\end{array}$ & $\begin{array}{l}0.2985 * * * \\
(0.0497)\end{array}$ & $\begin{array}{l}0.0670 * * * \\
(0.0149)\end{array}$ & & & \\
\hline $\begin{array}{l}\text { DISLOW at age } 18 \text { or } \\
\text { older }\end{array}$ & $\begin{array}{l}1.2843 \\
(0.3460)\end{array}$ & $\begin{array}{l}1.9983 * * * \\
(0.3647)\end{array}$ & $\begin{array}{l}2.7735 * * * \\
(0.7000)\end{array}$ & & & \\
\hline DISHIGH & & & & $\begin{array}{l}0.2939 * * * \\
(0.0834)\end{array}$ & $\begin{array}{l}0.2554 * * * \\
(0.0512)\end{array}$ & $\begin{array}{l}0.0514 * * * \\
(0.0134)\end{array}$ \\
\hline $\begin{array}{l}\text { DISHIGH at age } 18 \text { or } \\
\text { older }\end{array}$ & & & & $\begin{array}{l}0.8359 \\
(0.3156)\end{array}$ & $\begin{array}{l}1.1853 \\
(0.2863)\end{array}$ & $\begin{array}{l}1.1520 \\
(0.3559)\end{array}$ \\
\hline Age & $\begin{array}{l}1.2170 * * * \\
(0.0120)\end{array}$ & $\begin{array}{l}1.2483 * * * \\
(0.0107)\end{array}$ & $\begin{array}{l}1.9014 * * * \\
(0.0259)\end{array}$ & $\begin{array}{l}1.2216^{* * * *} \\
(0.0121)\end{array}$ & $\begin{array}{l}1.2507^{* * *} \\
(0.0108)\end{array}$ & $\begin{array}{l}1.9271 * * * \\
(0.0260)\end{array}$ \\
\hline Age squared & $\begin{array}{l}0.9971 * * * \\
(0.0001)\end{array}$ & $\begin{array}{l}0.9977 * * * \\
(0.0001)\end{array}$ & $\begin{array}{l}0.9921^{* * *} \\
(0.0002)\end{array}$ & $\begin{array}{l}0.9970 * * * \\
(0.0001)\end{array}$ & $\begin{array}{l}0.9977 * * * \\
(0.0001)\end{array}$ & $\begin{array}{l}0.9918^{* * *} \\
(0.0002)\end{array}$ \\
\hline No education diploma & Omitted & & & & & \\
\hline Completion of secondary & $2.1238 * * *$ & $0.3404 * * *$ & $0.4674 * * *$ & $2.1400 * * *$ & $0.3408 * * *$ & $0.4701 \% *$ \\
\hline & $(0.1366)$ & $(0.0203)$ & $(0.0412)$ & $(0.1372)$ & $(0.0203)$ & $(0.0414)$ \\
\hline Sex $($ male $=1 ;$ female $=0)$ & $\begin{array}{l}1.9721^{* * *} \\
(0.0601)\end{array}$ & $\begin{array}{l}0.6736 * * * \\
(0.0205)\end{array}$ & $\begin{array}{l}1.5603 * * * \\
(0.0646)\end{array}$ & $\begin{array}{l}1.9840 * * * \\
(0.0607)\end{array}$ & $\begin{array}{l}0.6779 * * * \\
(0.0207)\end{array}$ & $\begin{array}{l}1.6090 * * * \\
(0.0671)\end{array}$ \\
\hline Urban $($ yes $=1)$ & $\begin{array}{l}1.6867 * * * \\
(0.0779)\end{array}$ & $\begin{array}{l}0.3918 * * * \\
(0.0194)\end{array}$ & $\begin{array}{l}0.4540 * * * \\
(0.0247)\end{array}$ & $\begin{array}{l}1.6861 * * * \\
(0.0779)\end{array}$ & $\begin{array}{l}0.3909 * * * \\
(0.0193)\end{array}$ & $\begin{array}{l}0.4480 * * * \\
(0.0243)\end{array}$ \\
\hline Household size & $\begin{array}{l}0.9714 * * \\
(0.0133)\end{array}$ & $\begin{array}{l}1.0558 * * * \\
(0.0131)\end{array}$ & $\begin{array}{l}1.0285^{*} \\
(0.0159)\end{array}$ & $\begin{array}{l}0.9720 * * \\
(0.0133)\end{array}$ & $\begin{array}{l}1.0571 \% * * \\
(0.0132)\end{array}$ & $\begin{array}{l}1.0330 * * \\
(0.0158)\end{array}$ \\
\hline
\end{tabular}




\begin{tabular}{|c|c|c|c|c|c|c|}
\hline Household in North East & $\begin{array}{l}0.5020 * * * \\
(0.0345)\end{array}$ & $\begin{array}{l}2.3173 * * * \\
(0.1617)\end{array}$ & $\begin{array}{l}1.4348 * * * \\
(0.1125)\end{array}$ & $\begin{array}{l}0.4975 * * \\
(0.0342)\end{array}$ & $\begin{array}{l}2.3023 * * * \\
(0.1607)\end{array}$ & $\begin{array}{l}1.4083 * * * \\
(0.1108)\end{array}$ \\
\hline Household in North West & $\begin{array}{l}0.3307^{* * *} \\
(0.0355)\end{array}$ & $\begin{array}{l}3.5289 * * * \\
(0.3822)\end{array}$ & $\begin{array}{l}1.8697 * * * \\
(0.2593)\end{array}$ & $\begin{array}{l}0.3288 * * * \\
(0.0351)\end{array}$ & $\begin{array}{l}3.5075 * * * \\
(0.3802)\end{array}$ & $\begin{array}{l}1.8368 * * * \\
(0.2577)\end{array}$ \\
\hline \multirow[t]{2}{*}{$\begin{array}{l}\text { Household in North } \\
\text { Central Coast }\end{array}$} & 0.5257 & $1.5660 * * *$ & $0.8046^{* *}$ & $0.5255^{* * *}$ & $1.5653 * * *$ & $0.8103 * *$ \\
\hline & $(0.0398)$ & $(0.1121)$ & $(0.0690)$ & $(0.0398)$ & $(0.1121)$ & $(0.0690)$ \\
\hline $\begin{array}{l}\text { Household in South } \\
\text { Central Coast }\end{array}$ & 0.9735 & 0.9370 & 0.8653 & 0.9739 & 0.9386 & 0.8791 \\
\hline \multirow[t]{2}{*}{$\begin{array}{l}\text { Household in Central } \\
\text { Highlands }\end{array}$} & $0.5375^{* * *}$ & $2.0206 * * *$ & $1.2969 * *$ & $0.5331 * * *$ & $1.9983 * * *$ & $1.2589 * *$ \\
\hline & $(0.0549)$ & $(0.2081)$ & $(0.1454)$ & $(0.0544)$ & $(0.2054)$ & $(0.1396)$ \\
\hline Household in South East & $\begin{array}{l}1.2887 * * * \\
(0.0902)\end{array}$ & $\begin{array}{l}0.6487 * * * \\
(0.0479)\end{array}$ & $\begin{array}{l}0.7173 * * * \\
(0.0580)\end{array}$ & $\begin{array}{l}1.2825^{* * *} \\
(0.0894)\end{array}$ & $\begin{array}{l}0.6442 * * * \\
(0.0476)\end{array}$ & $\begin{array}{l}0.7016^{* * *} \\
(0.0563)\end{array}$ \\
\hline \multirow[t]{2}{*}{$\begin{array}{l}\text { Household in Mekong } \\
\text { River Delta }\end{array}$} & 1.0313 & 0.9636 & 0.9023 & 1.0285 & 0.9606 & 0.8946 \\
\hline & $(0.0651)$ & $(0.0589)$ & $(0.0660)$ & $(0.0647)$ & $(0.0589)$ & $(0.0650)$ \\
\hline
\end{tabular}

$* *$ Significant at $p<.01 ; *$ significant at $p<.05$; significant at $p<.1$.

Note: Numbers in parentheses are robust standard errors clustered at the commune level. DISLOW is the lower of two thresholds for determining when having difficulty performing activities becomes a disability; DISHIGH, the higher threshold, excludes people with lesser difficulties. DISLOW and DISHIGH (see box 1).

Source: Authors' analysis based on the 2006 Vietnam Household Living Standards Survey. 
Table A7. District Fixed Effects Logit Regression of Employment by Degree of Disability on People Ages 16-60 (Odds Ratios)

\begin{tabular}{|c|c|c|c|c|c|c|}
\hline Explanatory variable & $\begin{array}{l}\text { Worked for a wage or } \\
\text { salary }\end{array}$ & $\begin{array}{l}\text { Worked for the } \\
\text { household }\end{array}$ & $\begin{array}{l}\text { Had done any } \\
\text { work }\end{array}$ & $\begin{array}{c}\text { Worked for a wage } \\
\text { or salary }\end{array}$ & $\begin{array}{l}\text { Worked for the } \\
\text { household }\end{array}$ & $\begin{array}{l}\text { Had done any } \\
\text { work }\end{array}$ \\
\hline DISLOW & $\begin{array}{l}0.3155 * * * \\
(0.0648)\end{array}$ & $\begin{array}{l}0.2618 * * * \\
(0.0399)\end{array}$ & $\begin{array}{l}0.0498 * * * \\
(0.0083)\end{array}$ & & & \\
\hline $\begin{array}{l}\text { DISLOW at age } 18 \\
\text { or older }\end{array}$ & $\begin{array}{l}1.3364 \\
(0.3234)\end{array}$ & $\begin{array}{l}2.1272 * * * \\
(0.3740)\end{array}$ & $\begin{array}{l}3.0159 * * * \\
(0.5769)\end{array}$ & & & \\
\hline DISHIGH & & & & $\begin{array}{l}0.2574 * * * \\
(0.0624)\end{array}$ & $\begin{array}{l}0.2258 * * * \\
(0.0396)\end{array}$ & $\begin{array}{l}0.0390 * * * \\
(0.0073)\end{array}$ \\
\hline $\begin{array}{l}\text { DISHIGH at age } 18 \\
\text { or older }\end{array}$ & & & & $\begin{array}{l}0.9081 \\
(0.3020)\end{array}$ & $\begin{array}{l}1.3102 \\
(0.2909)\end{array}$ & $\begin{array}{l}1.4810 * \\
(0.3427)\end{array}$ \\
\hline Age & $\begin{array}{l}1.2273 * * * \\
(0.0109)\end{array}$ & $\begin{array}{l}1.2652 * * * \\
(0.0100)\end{array}$ & $\begin{array}{l}1.9576 * * * \\
(0.0243)\end{array}$ & $\begin{array}{l}1.2320 * * * \\
(0.0108)\end{array}$ & $\begin{array}{l}1.2673 * * * \\
(0.0100)\end{array}$ & $\begin{array}{l}1.9792 * * * \\
(0.0247)\end{array}$ \\
\hline Age squared & $\begin{array}{l}0.9970 * * * \\
(0.0001)\end{array}$ & $\begin{array}{l}0.9976 * * * \\
(0.0001)\end{array}$ & $\begin{array}{l}0.9917 * * * \\
(0.0002)\end{array}$ & $\begin{array}{l}0.9969 * * * \\
(0.0001)\end{array}$ & $\begin{array}{l}0.9975 * * * \\
(0.0001)\end{array}$ & $\begin{array}{l}0.9915 * * * \\
(0.0002)\end{array}$ \\
\hline
\end{tabular}




\begin{tabular}{|c|c|c|c|c|c|c|}
\hline \multirow{2}{*}{$\begin{array}{l}\text { Completion of } \\
\text { primary school }\end{array}$} & $0.8129 * * *$ & $1.2898 * * *$ & $1.1420 *$ & $0.8155 * *$ & $1.2892 * * *$ & $1.1425^{*}$ \\
\hline & $(0.0407)$ & $(0.0598)$ & $(0.0854)$ & $(0.0408)$ & $(0.0599)$ & $(0.0860)$ \\
\hline \multirow{2}{*}{$\begin{array}{l}\text { Completion of } \\
\text { secondary school }\end{array}$} & $1.9437 * * *$ & $0.3825 * * *$ & $0.4851 * * *$ & $1.9599 \div * *$ & $0.3839 * * *$ & $0.4920 * * *$ \\
\hline & $(0.1088)$ & $(0.0207)$ & $(0.0393)$ & $(0.1096)$ & $(0.0207)$ & $(0.0400)$ \\
\hline \multirow[t]{2}{*}{$\begin{array}{l}\text { Sex }(\text { male }=1 ; \\
\quad \text { female }=0)\end{array}$} & $2.0499 * * *$ & $0.6483 * * *$ & $1.5674 * * *$ & $2.0620 * * *$ & $0.6517 * * *$ & $1.6032 * * *$ \\
\hline & $(0.0654)$ & $(0.0200)$ & $(0.0676)$ & $(0.0658)$ & $(0.0201)$ & $(0.0694)$ \\
\hline Urban $($ yes $=1)$ & $(0.0732)$ & $(0.0268)$ & $(0.0388)$ & $(0.0732)$ & $(0.0268)$ & $(0.0388)$ \\
\hline \multirow[t]{2}{*}{ Household size } & $0.9691 * * *$ & $1.0447 * * *$ & 1.0070 & $0.9703 * * *$ & $1.0464 * * *$ & 1.0137 \\
\hline & $(0.0103)$ & $(0.0104)$ & $(0.0139)$ & $(0.0103)$ & $(0.0105)$ & $(0.0140)$ \\
\hline $\begin{array}{l}\text { Number of } \\
\text { observations }\end{array}$ & 23,938 & 24,383 & 24,037 & 23,938 & 24,383 & 24,037 \\
\hline Number of districts & 587 & 607 & 585 & 587 & 607 & 585 \\
\hline
\end{tabular}

$* *$ Significant at $p<.01 ; *$ significant at $p<.05$; significant at $p<.1$.

Note: Numbers in parentheses are robust standard errors clustered at the commune level. DISLOW is the lower of two thresholds for determining when having difficulty performing activities becomes a disability; DISHIGH, the higher threshold, excludes people with lesser difficulties. DISLOW and DISHIGH (see box 1).

Source: Authors' analysis based on the 2006 Vietnam Household Living Standards Survey. 
Table A 8. Enrollment Logit Results, Children Ages 6-17 (Odds Ratios)

\begin{tabular}{|c|c|c|c|c|c|c|}
\hline Explanatory variable & Model 1: logit & Model 2: logit & $\begin{array}{l}\text { Model 3: district fixed effect } \\
\text { logit }\end{array}$ & Model 1: logit & Model 2: logit & $\begin{array}{c}\text { Model 3: district fixed effect } \\
\text { logit }\end{array}$ \\
\hline DISLOW & $\begin{array}{l}0.1571 * * * \\
(0.0292)\end{array}$ & $\begin{array}{l}0.0842 * * * \\
(0.0206)\end{array}$ & $\begin{array}{l}0.0775 * * * \\
(0.0189)\end{array}$ & & & \\
\hline DISHIGH & & & & $\begin{array}{l}0.1179 * * \% \\
(0.0270)\end{array}$ & $\begin{array}{l}0.0682 * * * \\
(0.0200)\end{array}$ & $\begin{array}{l}0.0586^{* * *} \\
(0.0173)\end{array}$ \\
\hline Age & & $\begin{array}{l}0.6811 * * * \\
(0.0129)\end{array}$ & $\begin{array}{l}0.6907 * * * \\
(0.0097)\end{array}$ & & $\begin{array}{l}0.6825 * * * \\
(0.0130)\end{array}$ & $\begin{array}{l}0.6928 * * * \\
(0.0097)\end{array}$ \\
\hline Sex $($ male $=1 ;$ female $=0)$ & & $\begin{array}{l}0.7819 * * * \\
(0.0516)\end{array}$ & $\begin{array}{l}0.8106^{* * *} \\
(0.0559)\end{array}$ & & $\begin{array}{l}0.7811 * * * \\
(0.0516)\end{array}$ & $\begin{array}{l}0.8057 * * * \\
(0.0556)\end{array}$ \\
\hline Urban $($ yes $=1)$ & & $\begin{array}{l}1.3730 * * * \\
(0.1634)\end{array}$ & $\begin{array}{l}1.3703^{* * * *} \\
(0.1822)\end{array}$ & & $\begin{array}{l}1.3648 * * * \\
(0.1610)\end{array}$ & $\begin{array}{l}1.3716 * * * \\
(0.1824)\end{array}$ \\
\hline $\begin{array}{l}\text { Per capita income (million } \\
\text { dong) }\end{array}$ & & $\begin{array}{l}1.0736 * * * \\
(0.0161)\end{array}$ & $\begin{array}{l}1.0800 * * * \\
(0.0130)\end{array}$ & & $\begin{array}{l}1.0725 * * \\
(0.0161)\end{array}$ & $\begin{array}{l}1.0790 * * * \\
(0.0129)\end{array}$ \\
\hline Household size & & $\begin{array}{l}0.9371 * * * \\
(0.0234)\end{array}$ & $\begin{array}{l}0.9250 * * * \\
(0.0213)\end{array}$ & & $\begin{array}{l}0.9352 * * * \\
(0.0234)\end{array}$ & $\begin{array}{l}0.9240 * * * \\
(0.0213)\end{array}$ \\
\hline Household in Red River Delta & Omitted & & & & & \\
\hline Household in North East & & $\begin{array}{c}1.1286 \\
(0.1625)\end{array}$ & & & $\begin{array}{c}1.1331 \\
(0.1620)\end{array}$ & \\
\hline Household in North West & & $\begin{array}{c}0.7711 \\
(0.1534)\end{array}$ & & & $\begin{array}{c}0.7819 \\
(0.1556)\end{array}$ & \\
\hline $\begin{array}{l}\text { Household in North Central } \\
\text { Coast }\end{array}$ & & $\begin{array}{c}0.8336 \\
(0.1242)\end{array}$ & & & $\begin{array}{c}0.8344 \\
(0.1252)\end{array}$ & \\
\hline $\begin{array}{l}\text { Household in South Central } \\
\text { Coast }\end{array}$ & & $\begin{array}{c}1.1343 \\
(0.1872)\end{array}$ & & & $\begin{array}{c}1.1366 \\
(0.1853)\end{array}$ & \\
\hline $\begin{array}{l}\text { Household in Central } \\
\text { Highlands }\end{array}$ & & $\begin{array}{c}0.7460 \\
(0.1358)\end{array}$ & & & $\begin{array}{l}0.7619 \\
(0.1387)\end{array}$ & \\
\hline Household in South East & & $0.5678 * *$ & & & $0.5781 * *$ & \\
\hline
\end{tabular}



Household in Mekong River
Delta

Head without education degree

Head with primary school degree

Head with lower-secondary school

Head with upper secondary school

Head with technical degree

Head with post-secondary school

Number of observations

\section{(0.0903)}

$0.5385 * *$

(0.0716)

Omitted

$\begin{array}{ll}1.6258 * * * & 1.6487 * * * \\ & (0.1500) \\ (0.1463) & 2.7594 * * * \\ 2.8462 * * * & (0.3118) \\ & 4.0878 * * * \\ (0.3102) & (0.8216) \\ 4.5997 * * * & 7.6141 * * * \\ & (1.7817) \\ (0.8923) & 8.8110 * * * \\ 8.1011 * * * & \end{array}$

(0.0919)

$0.5466 * *$

(0.0727)

$\begin{array}{cc}1.6177 * * * & 1.6356 * * * \\ & \\ (0.1456) & (0.1488) \\ 2.8434 * * * & 2.7927 * * * \\ & (0.3156) \\ (0.3099) & 4.0552 * * * \\ 4.5951 * * * & (0.8151) \\ & 7.8381 * * * \\ (0.8915) & (1.8420) \\ 8.2482 * * * & 8.8640 * * * \\ (2.3425) & (4.0509) \\ 7.8538 * * * & 8,352 \\ (3.5421) & \end{array}$

$* *$ Significant at $p<.01 ; *$ significant at $p<.05$; significant at $p<.1$.

Note: Numbers in parentheses are robust standard errors clustered at the commune level. DISLOW is the lower of two thresholds for determining when having difficulty performing activities becomes a disability; DISHIGH, the higher threshold, excludes people with lesser difficulties. DISLOW and DISHIGH (see box 1).

Source: Authors' analysis based on the 2006 Vietnam Household Living Standards Survey. 
Table A9. Primary School Completion Logits by Disability Status at age 10, Adults Ages 18-62 (Odds Ratios)

\begin{tabular}{|c|c|c|c|c|c|c|}
\hline Explanatory variable & Model 1: logit & Model 2: logit & $\begin{array}{l}\text { Model 3: district fixed } \\
\text { effect logit }\end{array}$ & Model 1: logit & Model 2: logit & $\begin{array}{l}\text { Model 3: district fixed } \\
\text { effect logit }\end{array}$ \\
\hline DISLOW before age 10 & $\begin{array}{l}0.0631 \% * * \\
(0.0117)\end{array}$ & $\begin{array}{l}0.0269 * * * \\
(0.0075)\end{array}$ & $\begin{array}{l}0.0138 * * * \\
(0.0033)\end{array}$ & & & \\
\hline DISHIGH before age 10 & & & & $\begin{array}{l}0.0560^{* * *} \\
(0.0116)\end{array}$ & $\begin{array}{l}0.0223^{* * * *} \\
(0.0070)\end{array}$ & $\begin{array}{l}0.0103 * * * \\
(0.0028)\end{array}$ \\
\hline Age & & $\begin{array}{l}0.9512 * * * \\
(0.0019)\end{array}$ & $\begin{array}{l}0.9427 * * * \\
(0.0019)\end{array}$ & & $\begin{array}{l}0.9512 * * * \\
(0.0019)\end{array}$ & $\begin{array}{l}0.9427 * \cdots \\
(0.0019)\end{array}$ \\
\hline Sex $($ male $=1 ;$ female $=0)$ & & $\begin{array}{l}1.6871 * * * \\
(0.0624)\end{array}$ & $\begin{array}{l}1.8349 * * * \\
(0.0752)\end{array}$ & & $\begin{array}{l}1.6837 * * * \\
(0.0623)\end{array}$ & $\begin{array}{l}1.8331 * * * \\
(0.0752)\end{array}$ \\
\hline Urban $($ yes $=1)$ & & $\begin{array}{l}2.2910^{* * * *} \\
(0.1833)\end{array}$ & $\begin{array}{l}2.7020 * * * \\
(0.1999)\end{array}$ & & $\begin{array}{l}2.2887^{* * * *} \\
(0.1831)\end{array}$ & $\begin{array}{l}2.6885^{* * *} \\
(0.1963)\end{array}$ \\
\hline $\begin{array}{l}\text { Per capita income (million } \\
\text { dong) }\end{array}$ & & $1.1377 * * *$ & $1.1480^{* * * *}$ & & $1.1388^{* * * *}$ & $1.1491 \% *$ \\
\hline Household size & & $\begin{array}{l}(0.0137) \\
0.9194 * * * \\
(0.0156)\end{array}$ & $\begin{array}{c}(0.0069) \\
0.9734^{* * *} \\
(0.0117)\end{array}$ & & $\begin{array}{l}(0.0137) \\
0.9213 * * * \\
(0.0157)\end{array}$ & $\begin{array}{l}(0.0069) \\
0.9753 * * * \\
(0.0117)\end{array}$ \\
\hline $\begin{array}{l}\text { Household in Red River } \\
\text { Delta }\end{array}$ & Omitted & & & & & \\
\hline Household in North East & & $\begin{array}{l}0.2549 * * * \\
(0.0285)\end{array}$ & & & $\begin{array}{l}0.2541 * * * \\
(0.0285)\end{array}$ & \\
\hline Household in North West & & $\begin{array}{l}0.0883 * * * \\
(0.0123)\end{array}$ & & & $\begin{array}{l}0.0887 * * * \\
(0.0123)\end{array}$ & \\
\hline $\begin{array}{l}\text { Household in North Central } \\
\text { Coast }\end{array}$ & & $0.5262 * * *$ & & & $0.5278 * * *$ & \\
\hline & & $(0.0700)$ & & & $(0.0702)$ & \\
\hline $\begin{array}{l}\text { Household in South Central } \\
\text { Coast }\end{array}$ & & $\begin{array}{l}0.2078^{* * *} \\
(0.0260)\end{array}$ & & & $\begin{array}{l}0.2095 * * \\
(0.0264)\end{array}$ & \\
\hline
\end{tabular}


Household in Central

Highlands

Household in South East

Household in Mekong River

Delta

Number of observations

$0.1116^{* * *}$

$(0.0152)$

$0.1143^{* * *}$

$(0.0133)$

$0.0669^{* * *}$

$(0.0064)$
$0.1109 * * *$

(0.0151)

$0.1147 * * *$

(0.0134)

$0.0671 * * *$

$(0.0065)$

23,012
21,368

$* * *$ Significant at $p<.01 ; * *$ significant at $p<.05$; significant at $p<.1$.

Note: Numbers in parentheses are robust standard errors clustered at the commune level.

Source: Authors' analysis based on the 2006 Vietnam Household Living Standards Survey. 
Table A10. Secondary School Completion Logits by Disability Status, Adults Ages 18-62 (Odds Ratios)

\begin{tabular}{|c|c|c|c|c|c|c|}
\hline Explanatory variable & Model 1: logit & Model 2: logit & $\begin{array}{l}\text { Model 3: district fixed } \\
\text { effect logit }\end{array}$ & Model 1: logit & Model 2: logit & $\begin{array}{l}\text { Model 3: district fixed } \\
\text { effect logit }\end{array}$ \\
\hline DISLOW before age 17 & $\begin{array}{l}0.1520 * * * \\
(0.0426)\end{array}$ & $\begin{array}{l}0.1185^{* * *} \\
(0.0389)\end{array}$ & $\begin{array}{l}0.1161^{* * *} \\
(0.0332)\end{array}$ & & & \\
\hline DISHIGH before age 17 & & & & $\begin{array}{l}0.1812 * * * * \\
(0.0536)\end{array}$ & $\begin{array}{l}0.1488^{* * * *} \\
(0.0500)\end{array}$ & $\begin{array}{l}0.1372 * * * * \\
(0.0424)\end{array}$ \\
\hline Age & & $\begin{array}{l}0.9550 * * * \\
(0.0019)\end{array}$ & $\begin{array}{l}0.9522 * * * \\
(0.0019)\end{array}$ & & $\begin{array}{l}0.9550 \% \cdots \\
(0.0019)\end{array}$ & $\begin{array}{l}0.9531^{* \cdots} \\
(0.0019)\end{array}$ \\
\hline $\begin{array}{l}\text { Sex }(\text { male }=1 \\
\quad \text { female }=0)\end{array}$ & & $\begin{array}{l}1.4492 \% * * \\
(0.0449)\end{array}$ & $\begin{array}{l}1.5235 \% * \% \\
(0.0518)\end{array}$ & & $\begin{array}{l}1.4477 \% * * \\
(0.0449)\end{array}$ & $\begin{array}{l}1.5204 \% * \\
(0.0517)\end{array}$ \\
\hline Urban $($ yes $=1)$ & & $\begin{array}{l}3.2871^{* * *} \\
(0.1972)\end{array}$ & $\begin{array}{l}3.1740 * * * \\
(0.1746)\end{array}$ & & $\begin{array}{l}3.2838^{* * *} \\
(0.1970)\end{array}$ & $\begin{array}{l}3.1772 * * * \\
(0.1747)\end{array}$ \\
\hline $\begin{array}{l}\text { Per capita income } \\
\text { (million dong) }\end{array}$ & & $\begin{array}{l}1.1052 \% * \\
(0.0077)\end{array}$ & $\begin{array}{l}1.1041 * * * \\
(0.0033)\end{array}$ & & $\begin{array}{l}1.1052^{* * *} \\
(0.0077)\end{array}$ & $\begin{array}{l}1.1041^{* * *} \\
(0.0033)\end{array}$ \\
\hline Household size & & $\begin{array}{l}0.9380^{* * * * *} \\
(0.0141)\end{array}$ & $\begin{array}{l}0.9550 * * * \\
(0.0115)\end{array}$ & & $\begin{array}{l}0.9389 * \cdots * * \\
(0.0141)\end{array}$ & $\begin{array}{l}0.9550^{* * * *} \\
(0.0115)\end{array}$ \\
\hline $\begin{array}{l}\text { Household in Red River } \\
\text { Delta }\end{array}$ & Omitted & & & & & \\
\hline $\begin{array}{l}\text { Household in North } \\
\text { East }\end{array}$ & & $\begin{array}{l}0.7672 * * * \\
(0.0598)\end{array}$ & & & $\begin{array}{l}0.7664 * * * \\
(0.0598)\end{array}$ & \\
\hline $\begin{array}{l}\text { Household in North } \\
\text { West }\end{array}$ & & $0.4848 * *$ & & & $0.4853 * *$ & \\
\hline & & $(0.0664)$ & & & $(0.0665)$ & \\
\hline $\begin{array}{l}\text { Household in North } \\
\text { Central Coast }\end{array}$ & & $\begin{array}{l}0.8033 \% * \\
(0.0707)\end{array}$ & & & $\begin{array}{l}0.8033 \% * \\
(0.0707)\end{array}$ & \\
\hline
\end{tabular}


Household in South

Central Coast

Household in Central

Highlands

Household in South

East

Household in Mekong

River Delta

Number of observations

Note: Numbers in parentheses are robust standard errors clustered at the commune level.

Source: Authors' analysis based on the 2006 Vietnam Household Living Standards Survey.
$0.5781 * * *$

(0.0532)

$0.4173 * * *$

\section{$(0.0476)$}

$0.3914 * * *$

$(0.0352)$

$0.2165 * *$

$0.2161 *$

(0.0178)

23,012 